\title{
A Sephardic Saga in the Dutch Republic: The Cohen Pallache Women on Love, Religion, and Social Standing
}

\author{
Tirtsah Levie Bernfeld
}

\section{Introduction}

The Portuguese community in the Dutch Republic carefully guarded the image it presented to the outside world. The parnassim and rabbis repeatedly reminded members to act with decorum and bom judesmo. Yet, the Sephardim in the Dutch Republic had their fair share of scandal. The true story of the clandestine courtship of Eva Cohen, the petite, dark-haired daughter of the wealthy Cohen Pallache family that resided in Delft from the late 166os till the early 1680s, and Michiel Verboon, a young, tall, fair-skinned, blond and curly-haired Gentile servant in the household of Eva's brother Jacob in The Hague, has all the makings of a novel of historical fiction: family upheaval, risk of family honor, status, and wealth, tarnishing of faith, and even high court drama.

The affair began in secret, but its subsequent handling over the course of four years eventually became a very public matter, reaching the "Hoge Raad," the Supreme Court of the Dutch Republic. ${ }^{1}$ Rebecca Pallache Cohen, Eva's widowed mother challenged the young couple's intended union in a lawsuit that was brought in front of the Dutch courts. Though the young woman was an adult and could marry without the consent of her parents, according to Dutch law the alliance could be protested if objections of substance could be shown. ${ }^{2}$ Rebecca Pallache complained of the inequality of the alliance, though

1 National Archives The Hague (henceforth: NL-HaNA), Hof van Holland entry no. 3.03.01.o1, inv. no. 5331. 29, different documents dated 1680-1684; NL-HaNA, Hoge Raad van Holland en Zeeland, entry no. 3.03.02, inv. no. 267, scan no. 17, 1682 [no date, most probably January]; ibid., inv. no. 903, 9 July 1683, scan no. 135; ibid., inv. no. 903, 8 July 1684, scan no. 216; ibid. inv. no. 903, 22 July 1684, scan no. 221; see for a description of the affair in the paper "Den Galanten Mercurius" (1684), 18-23; a more extensive analysis of the judicial trial and procedure of the affair between Eva Cohen and Michiel Verboon, both before Dutch and English courts will be discussed by the author at a later stage.

2 For a discussion of the restrictions on marriage see Lambertus J. van Apeldoorn, Geschiedenis van het Nederlandsche huwelijksrechtvóór de invoering van de Franschewetgeving (Amsterdam: Holland, 1925), 126-70. Donald Haks, Huwelijk en Gezin in de 17de en 18de Eeuw (Assen: van

(C) TIRTSAH LEVIE BERNFELD, 2019 | DOI:10.1163/9789004392489_009

This is an open access chapter distributed under the terms of the prevailing CC-BY-NC License at the time of publication. 
this would not have been considered sufficient reason for the court to prevent the marriage from taking place. ${ }^{3}$ The case generated a large number of court documents and archival files and also a small printed pamphlet published in English and in Dutch (Fig. 8.1). ${ }^{4}$ The Amsterdam Portuguese community, likely aware of the situation concerning the Cohen Pallache family, kept its distance from the matter, though the London Portuguese community had no choice but to become publicly involved in it. ${ }^{5}$

The wealthy Sephardic family that Eva belonged to maintained close connections with the elite circles of Jewish and non-Jewish society in the Dutch Republic and beyond. ${ }^{6}$ Eva's father Abraham Cohen had links to the Amsterdam

Gorcum, 1982), 115; Eva must have been more than twenty years old by then and thus did not need to ask for permission to marry (see Burnet, De ware bekeringe, 3: Eva's father having died before she was twelve; her father died in 1671 which was around nine years before the pamphlet was written). Michiel, on the other hand, was older, but at age twenty-three in 1680 he was not able to marry without the permission of his parents. Still, he told friends that it was only a short time until he would be twenty-five, and could marry without their consent; see interview with Jacobus Bradly, NL-HaNA, Hof van Holland entry no. 3.03.01.01, inv. no. 5331. 29, 26 June 1681.

3 See for a similar case of unequal partners in a non-Jewish milieu, Machiel Bosman, Elisabeth de Flines. Een onmogelijke liefde in de achttiende eeuw (Amsterdam: Athenaeum-Polak and Van Gennep, 2008), 46-47, 97-98; the files of the Hof van Holland contain many cases of unequal couples consisting of wealthy women and men of lower status, see Haks, Huwelijk en Gezin, 117-19, 128-35.

4 Gilbert Burnet, De ware bekeringe en violente vervolgingen van Eva Cohen, nu genaemt Elisabeth. Zijnde een persoon van qualiteyt vande Joodsche gesintheyt geweest, ende gewoont hebbend tot Delft; dewelke gedoopt is den 10. October, 1680 in St. Martins Kerck, des Coninghs Parochie van Whitehall, door den seer Eerwaardieghen Heer William Floid, bisschop van St. Asaph (n.p., n.d.). Uytgegeven in het Engels door den Hoogeleerden Heer Gilbert Burnet, Theologiae Professor en Doctor, nu getranslateert in het Nederduyts[London], [1681], 3-4; the original English title: G. Burnet, The Conversion \& Persecutions of Eve Cohan, Now called Elizabeth Verboon A Person of Quality of the Jewish Religion. Who was Baptized the roth of October 1680, at St. Martins in the Fields, By the Right Reverend Father in God, William, Lord Bishop of St. Asaph (London, 1680). For the description of the appearance and clothing of Eva Cohen and Michiel Verboon, see NL-HaNA, Hof van Holland entry no. 3.03.01.01, inv. no. 5331.29, testimony of Jeronimo Poens, Mechelen, 19 July 1681; for that of Michiel Verboon, see also ibid., testimony of Francois Valentijn, the innkeeper of Court of Spain in Brussels, 8 July 1681; and ibid., the testimony of a neighbor of the Cohen family in Delft, Andries Coster and his wife Anna Cupers before notary Cornelis Ouwendijck of Delft, Delft, 13 June 1681.

5 Or rather, its representative responsible for contact with the local authorities. See Albert M. Hyamson, The Sephardim of England, A History of the Spanish and Portuguese Jewish Community 1492-1951 (London: Methuen, 1951), 56.

6 Aernout van Woestinghove, a former cornet of the guard of Prince Johan Maurits van Nassau, refused to elaborate about Michiel having often spent the night with Eva when she stayed in his home. For this reason he also had prohibited his wife to talk about it or to report it to Jacob Cohen, even though he had his suspicions (NL-HaNA, Hof van Holland, entry no. 


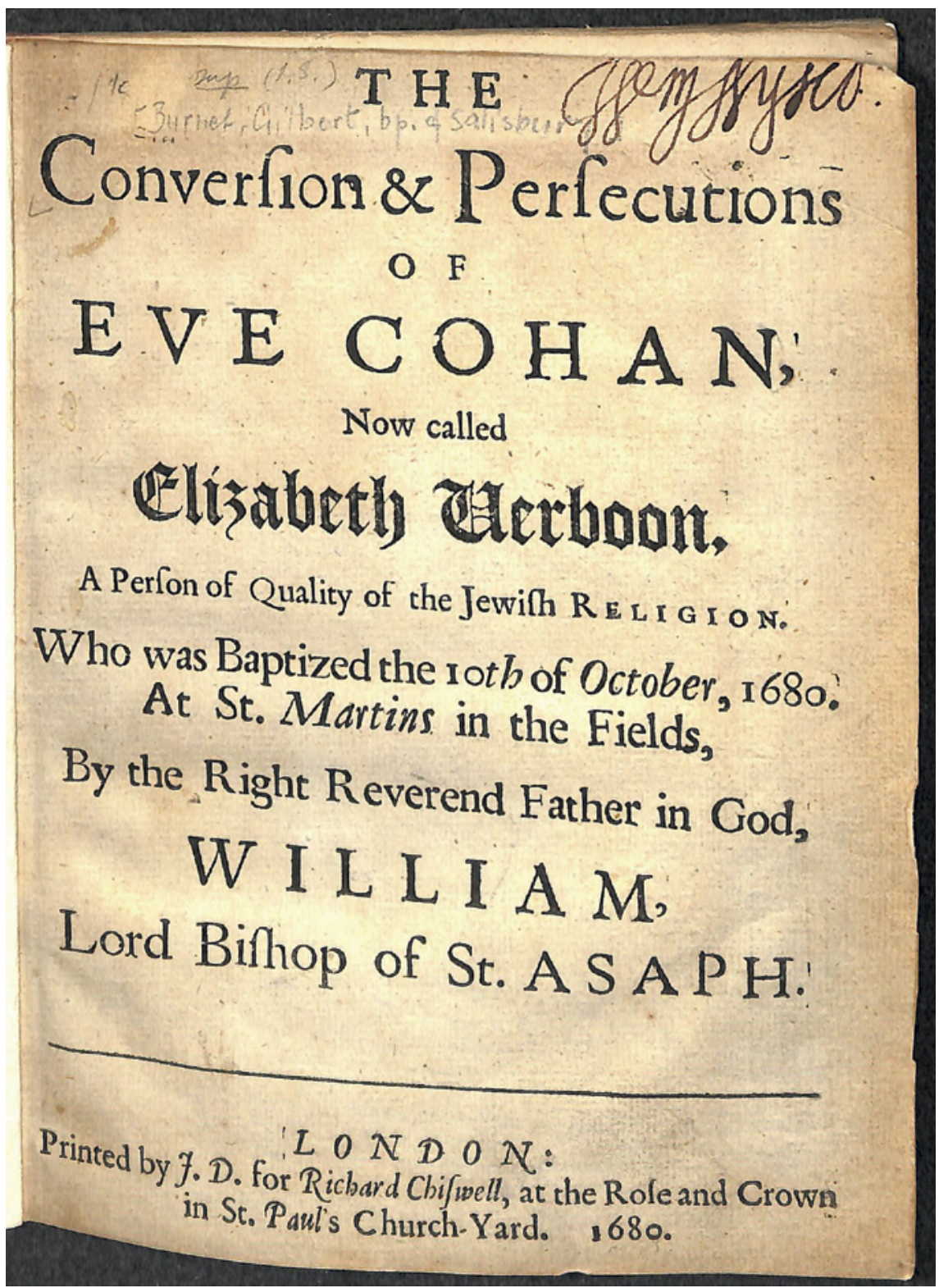

FIGURE 8.1 Frontispiece of the pamphlet The Conversion \& Persecutions of Eve Cohan, Now called Elizabeth Verboon [...], by Gilbert Burnet, London, 1680, National Library of Israel, Jerusalem 
Portuguese community but it is not certain he was ever officially a member. The community's records list his attendance at a funeral in 1629 , and in 1656 , he took over a relative's membership in the Amsterdam-based international dowry society, Dotar. ${ }^{7}$ While he lived for a time in Amsterdam, his name does not appear regularly on the list of the communal taxpayers though he is listed as having made voluntary contributions (promessas) during synagogue services. A possible explanation for his lack of membership is that he was often abroad on business. Stationed in Dutch Brazil until 1654, his signature, in Hebrew, appears in the communal registers of the Portuguese Jews there. ${ }^{8} \mathrm{He}$ eventually returned to the Netherlands, and settled in Delft in 1669. Besides the Dotar membership and the infrequent voluntary contributions, his name appears again in the Amsterdam Portuguese community registry in 1671, when his widow, Rebecca Pallache, sent money to the Amsterdam Portuguese synagogue for prayers to be recited in his memory on the eves of the new months and during the nights of Yom Kippur. She also insisted that mention of this legacy be made on each Shabbat ha-Gadol (the Sabbath before Passover), her wish expressing family pride and a notion of social standing. ${ }^{9}$

3.03.01.01, inv. no. 5331. 29, testimony of Aernout van Woestinghove, before notary Jeremias Stael, The Hague, 16 June 1681).

7 Stadsarchief Amsterdam [hereafter SAA] 334, inv. no. 1, p. 54v/88, 5389. Relating to Dotar see: SAA 334, inv. no. 1141, p. 7/5, 14 Adar 5375; in 5416 Abraham Cohen is admitted as a member of Dotar-apparently after his return from Brazil—instead of his "father Joseph Cohen" (sic! his father was called Mordechay; in 1661 Abraham was described only as the descendant of Joseph Cohen) and signs in Latin letters: SAA 334, inv. no. 1143, p. 254/119, 13 Adar 5416; see also SAA 334, inv. no. 1143, p. 21/3, 5421 "Notta de Hirmaons que the oje [...] hao emtrado na santa companhia de dottar orphans e donçelas povres": no. 14: "Abraham Cohen, dezte de Josseph Cohen." Abraham's father was called Mordechay as can be read on the text of his tombstone: Isaac S. Emmanuel, "Seventeenth-Century Brazilian Jewry: A Critical Review," American Jewish Archives 14, no. 1 (April 1962): 62: Abraham ben Mordechay do Brazil (אברהם בן מרדכי כהן דו בראזיל). For further data on Abraham Cohen see sources and literature mentioned in Egon and Frieda Wolff, Dicionário Biográfico, Judaizantes e Judeus no Brasil 1500-1808 (Rio de Janeiro: E. \& F. Wolff, 1986), 1: 40-41. On Dotar see Miriam Bodian, "The 'Portuguese' Dowry Societies in Venice and Amsterdam: A Case Study in Communal Differentation within the Marrano Diaspora," Italia 6, nos. 1-2 (1987): 30-61; Tirtsah Levie Bernfeld, Dowries and Dotar. An Unbroken Chain of 400 Years (Amsterdam: Menasseh ben Israel Institute, 2015).

8 On Abraham Cohen as a member of the Portuguese Zur Israel community in Brazil, see Arnold Wiznitzer, Jews in Colonial Brazil (New York: Columbia University Press, 1960), 137; for him signing in Hebrew see below n. 60.

9 See Livro de Escamot SAA 334, inv. no. 19, p. 645, 21 Tevet 5432: 200 guilders; ibid., inv. no. 174, p. 857,7 Adar II 5432 . On charity sustained by piety and charity given out of considerations of prestige see Tirtsah Levie Bernfeld, Poverty and Welfare among the Portuguese Jews in Early Modern Amsterdam (Oxford: The Littman Library of Jewish Civilization, 2012), 159-71, 178-80. 
After Abraham's death, his oldest son Jacob became a member of the Amsterdam Portuguese community, and as of 1672 , he was registered as paying ten guilders per year in communal taxes. ${ }^{10}$ Eva's parents and siblings are buried at the cemetery in Ouderkerk aan de Amstel, the burial place for members of the Amsterdam Portuguese community, another proof of their connection to the Sephardic milieu. ${ }^{11}$

The Pallache family's affiliation with Judaism is less straightforward. A few members of this well-known family of diplomats of Moroccan Jewish descent had converted to Christianity. ${ }^{12}$ Isaac Pallache, Eva's grandfather, converted in Jutphaas (near Utrecht) in 1627, and apparently, he had some, if not all, of his children baptized, including Rebecca Pallache, Eva's mother. His conversion

10 Some of the persons mentioned on the list in the Escamot, were registered as persons coming from outside ("alguas pessoas vindas de fora"). Others had not been taxed before. It is not clear what case could be applied to Jacob. I assume the first option. This Jacob apparently attended services at the Portuguese synagogue of Amsterdam quite often since he regularly paid contributions there, while a relatively high sum was promised during services around his mother's death (for the amount of $f 63$, 10 given as promessas see SAA 334, inv. no. 175, p. 311, 1 Elul 5445); for Jacob Cohen assessed for paying the finta tax: SAA 334 , inv. no. 19, p. 656,5 Elul $5432 f$ 10: just a few months apparently after his father died. Jacob continued to pay taxes during the 1670 os and ' 80 s as Jacob Cohen de Abraham and also attended synagogue services regularly, as he paid promessas: see for example: SAA 334, inv. no. 174, p. 1002, 1 Hesvan 5434; ibid., p. 1019, 7 Nisan 5434; ibid., p. 1040, 7 Tishri 5435; SAA 334, inv. no. 175, p. 16o, 29 Elul 5441; ibid., p. 174, 1 Nisan 5442; ibid., p. 230, 26 Elul 5443; ibid., p. 285, 5445 [s.d.]; ibid., p. 311, 1 Elul 5445; ibid., p. 329, 18 Adar 5446; ibid., inv. no. 19, p. 717, 24 Shevat 5435; I could find no trace of him as a member of the Dotar dowry society.

11 For Abraham's grave see: https://www.dutchjewry.org/phpr/amsterdam/port_isr_gem _ burials/amsterdam_port_isr_gem_burials_view.php?editidı=5262; 5432 is given as the year of death; apparently his tombstone was made of marble, and was engraved with two hands, the symbol of kohanim, as well as a skull and bones. For notes on the burial of Rebecca Pallache at the Portuguese Jewish cemetery in Ouderkerk, see SAA 334, inv. no. 916, p. 49/17: "em 28 ditto se enterou a mulher de Abraham Coem de Brazil." For the sons Joseph, Jacob, Moses, and Mordechay and daughter Ester, also called Hester, see https://www.dutchjewry.org/phpr/amsterdam/port_isr_gem_burials/amsterdam_port_ isr_gem_burials_view.php?editidı=19141. The burial place at Ouderkerk of Mordechay, who married a non-Jew, was described as a place "worse than that for the slaves." Yet apparently it was very important for the family to have his body laid to rest at a Jewish cemetery: Mercedes García-Arenal and Gerard Wiegers, Samuel Pallache. Koopman, kaper en diplomaat tussen Marrakesh en Amsterdam (Amsterdam: Amsterdam University Press 2014), 231; see also for the epitaphs of Abraham and Rebecca, Emmanuel, "SeventeenthCentury Brazilian Jewry," 62.

García-Arenal and Wiegers, Samuel Pallache, $136-38$. 
might have been motivated by economic or political factors, which calls its sincerity into question, especially in light of his later return to Judaism. ${ }^{13}$

Despite his purported baptism, Isaac's children received a Jewish education at home. This fact was attested to by Hakham Samuel Tardiola, a rabbi originally from Jerusalem who was active among the Portuguese community in Amsterdam. Hakham Tardiola affirmed that Isaac had told him that his children knew nothing about Christianity but knew all the Jewish prayers in Hebrew. Moreover, Isaac had confided in him that in Leiden, where Isaac Pallache resided with his family, they observed the Jewish Sabbath, holidays, and dietary laws. ${ }^{14}$

Eva's father, Abraham Cohen, an important and highly esteemed figure in Brazil, married his niece Rebecca Pallache, daughter of Isaac Pallache, in Brazil around the year 1652 . He was an overseer of Dutch plantations as well as a plantation and ship owner, army provider, broker, and slave trader. ${ }^{15}$ Cohen

13 Isaac Pallache called himself a professor of Hebrew at Leiden University, yet might have been just a student there: ibid., 220-26, 282-84. Hugo de Groot, Remonstrantie nopende de ordre dije in de landen van Hollandt ende Westvrieslandt dijent gestelt op de Joden, ed. (with an introduction) by Jaap Meijer (Amsterdam, 1949 [5709]), 29-30, n. 57; the sister of Rebecca, Hester Pallache, was described by the Reformed Church as a child born from Christian parents: SAA 376, inv. no. 12, p. 319, 6 July 1673. Isaac Pallache is also discussed in the pamphlet about Eva Cohen, Burnet, De ware bekeringe, 3-4.

14 García-Arenal and Wiegers, Samuel Pallache, 221-26. On Isaac Pallache see further Herman Roodenburg, Onder Censuur. De kerkelijke tucht in de gereformeerde gemeente van Amsterdam, 1578-1700 (Hilversum: Verloren, 1990), 188-89; see also notes and literature mentioned in Hugo de Groot, Remonstrantie, 29-30, n. 57.

15 On Abraham Cohen and Rebecca Pallache in Brazil: Wolff, Dicionário Biográfico, 1: 40-41, 149-50; José A. Gonsalves de Mello, Gente de Nação: Cristãos-Novos e Judeus em Pernambuco, 1542-1654 (Recife: Massangana, 1989), index Cohen, Abraão Martensen and summary of his political and economic activities in Dutch Brazil on 372-73; on Abraham Cohen as a member of the Portuguese Jewish community in Brazil, see Wiznitzer, Jews in Colonial Brazil, 126, 137, 171, 174; García-Arenal and Wiegers, Samuel Pallache, 222, 227, 230; for Abraham Cohen and his contacts with Prince Johan Maurits, A. Hulshof, "Een Duitsch econoom in en over ons land omstreeks 1670," Onze Eeuw 10 (1910): 73; for Abraham Cohen as a main shareholder of the West Indian Company and as someone having great influence in that company who could introduce the German economist Johan Joachim Becher to the other shareholders in 1669, see again Hulshof, "Een Duitsch econoom," 73. Apparently Cohen was paid for his intervention: ibid., 78. On Abraham Cohen as a slave trader and his relations to the West Indian Company see also Jaap Meijer, Encyclopaedia Sefardica Neerlandica (Amsterdam: Portugees-Israelietische Gemeente Amsterdam, 5709-5710 [1948-1950]), 1: 152. See also the poem on Abraham Cohen by Daniel Levi de Barrios, Gonsalves de Mello, Gente de Nação, 373; for the value of property claimed in the 166os from the Portugese empire after the surrender of Dutch Brazil, see Emmanuel, "Seventeenth-Century Brazilian Jewry," 51; Abraham Cohen was one of the five most 
was also the agent of the Dutch government in Brazil whose headquarters were in Recife, and consequently he had excellent contacts with the governor of Dutch Brazil, Johan Maurits van Nassau. His marriage to Rebecca Pallache appears to have been his second, and must have been officiated by the famous Hakham Isaac Aboab da Fonseca who, a few months earlier, had performed the hupah (Jewish wedding ceremony) of Cohen's other niece Eva, Rebecca's sister, who had married an Ashkenazic Jew by the name of Simon Mayer. ${ }^{16}$ Eva's wedding was performed in Cohen's house in Recife. Cohen apparently paid for her dowry (which included one of his houses in Recife and a slave girl) and wrote the marriage settlement in Portuguese, which was translated into Hebrew by Aboab. ${ }^{17}$ Abraham and Rebecca kept in touch with Hakham Isaac Aboab da Fonseca, even after their return to the Dutch Republic. In fact, as late as 1681, Aboab made a declaration in Amsterdam at the request of Rebecca Pallache. ${ }^{18}$ Arriving from Brazil to Amsterdam, the Cohen Pallache family first took up residence in St Antonibreestraat, in the heart of Amsterdam's Jewish district. ${ }^{19}$ Abraham, still a leading figure in the Dutch West Indian company, continued to travel abroad for business and was involved in the colonization of overseas territories of Cayenne, Guyana, and Curaçao. ${ }^{20}$ Later, for unknown reasons, the family moved to Delft. One possible explanation for the move was it being at the time the third largest city in the Dutch Republic with a chamber of the West Indian Company in addition to offices and warehouses of the East Indian Company (Fig. 8.2). It was also in proximity to The Hague with its diplomatic

prominent Jews in Dutch Brazil: ibid., 157; also in the pamphlet on the conversion of Eva Cohen, her father Abraham Cohen is described as a very wealthy merchant: Burnet, $D e$ ware bekeringe, 3 .

16 Meijer, Encyclopaedia Sefardica, 1: 152; See on this Eva Pallache in Wolff, Dicionário Biográfico,1: 149-50; Gonsalves de Mello, Gente de Nação, 247, 422.

17 SAA 5075, inv. no. 3686, Not. F. Tixerandet, pp. 666-68, June 1681 [date of day impossible to read]: Declaration of Isaac Aboab da Fonseca on behalf of Rebecca Pallache, widow of Abraham Cohen: on 20 Elul 5412/25 August 1652 at home with Abraham in Brazil the marriage was performed between Eva Pallache and Simon Mayer. For houses and ground bought by Abraham Cohen in Recife: Gonsalves de Mello, Gente de Nação, 347-48; see also pages via index Cohen, Abraão Martensen.

18 García-Arenal and Wiegers, Samuel Pallache, 222, 314, n. 72.

19 Richard Kagan and Philip D. Morgan, eds., Atlantic Diasporas. Jews, Conversos and CryptoJews in the Age of Mercantilism, 1500-1800 (Baltimore:The Johns Hopkins University Press, 2009), 34, 48; for the family of Abraham Cohen living in St. Anthonibreestraat, Hulshof, "Een Duitsch econoom," 73; Meijer, Encyclopaedia Sefardica, 1: 152.

20 Herbert I. Bloom, "The Dutch Archives with Special Reference to American Jewish History," Publications of the American Jewish Historical Society 32 (1931): 16. 


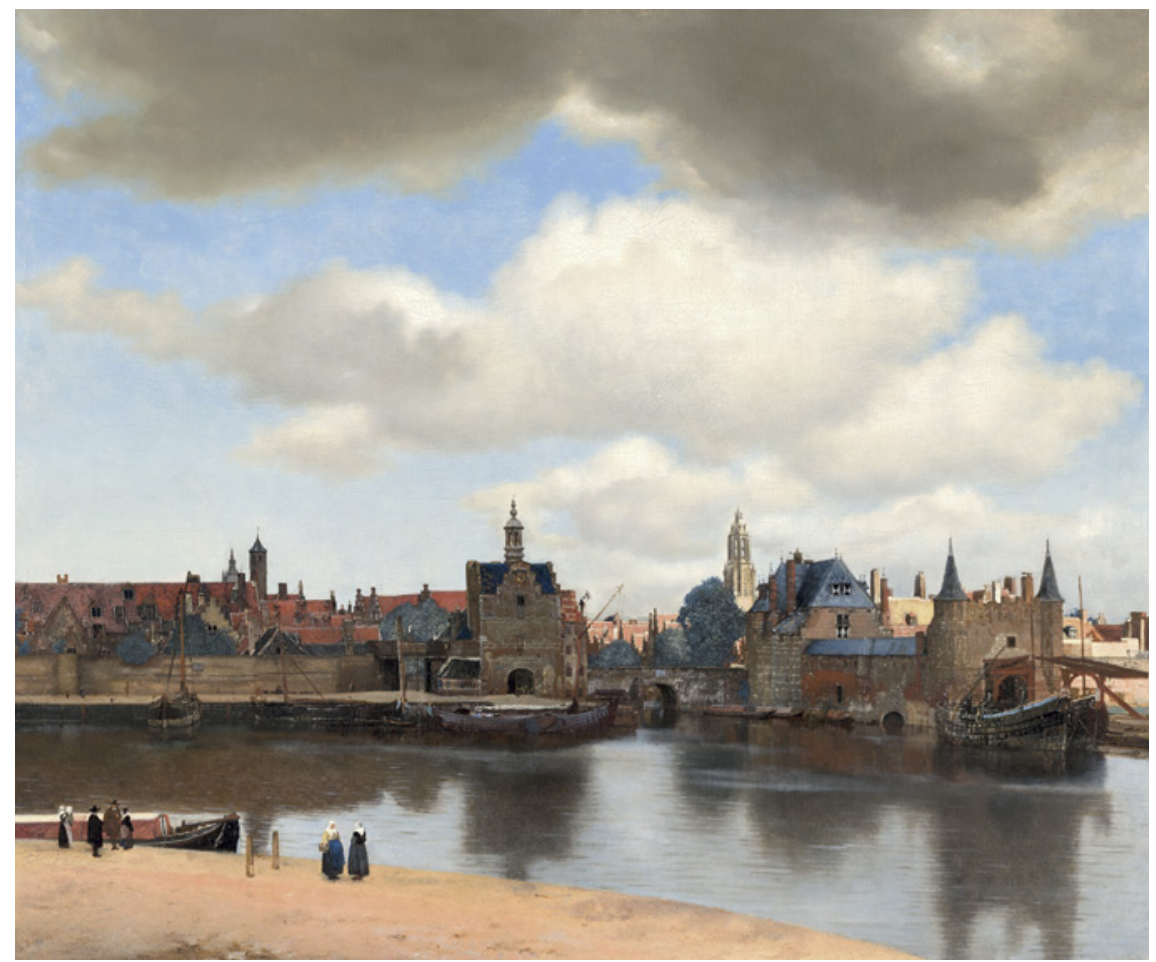

FIGURE 8.2 Johannes Vermeer, View of Delft, c. 166o-1661, Mauritshuis, The Hague

circles and was within easy reach of Rotterdam, Leiden, and Amsterdam. ${ }^{21}$ The family frequently traveled to The Hague and Amsterdam to visit family

21 Delft, together with Rotterdam and Dordrecht, formed one of the five chambers of the West Indian Company (WIC). Isaac Pallache, Abraham's brother-in-law and father-in-law had been involved in wIC Delft: García-Arenal and Wiegers, Samuel Pallache, 229-30. This chamber of the wic was called "Kamer van Maze": six out of the fourteen seats of this "Kamer van Maze" were reserved for The Hague; two seats, each in its turn, represented this chamber in the head office. Margaretha E. van Opstall, "De kamer van de Maze tot Delft," De stad Delft. Cultuur en Maatschappij van 1572 tot 1667, ed. Ineke V.T. Spaander (Delft: Stedelijk Museum "Het Prinsenhof", 1981), 2: 94-96. In 1674 the wIC was refounded, now with only thirty members; two represented Delft; one of them represented the "Kamer van Maze" at the headquarters: Gerrit Verhoeven, De derde stad van Holland. De geschiedenis van Delft tot 1795 (Zwolle: WBOOKS, 2015), 1: 299. As of 1669 most activities were transferred to Rotterdam. The Delft office was sold (Verhoeven, De derde stad van Holland, 299-300). As far as the East Indian Company (VOC) is concerned, since 1602, there was a chamber in Delft representing this company with seven members out of the total of sixty: Loet Schledorn, "De kamer van Delft van de voc: een rijke bron," in Burgers verzamelen, 1600-1750 Schatten in Delft 1602-2002; 400 jaar Verenigde Oost-Indische 
and friends. ${ }^{22}$ Abraham Cohen died in Delft in 1671 and, as mentioned, was buried in the Portuguese Jewish cemetery in Ouderkerk. Rebecca Pallache remained in Delft for another ten years where she continued to raise five of her six children. Her eldest son Jacob Cohen, perhaps at his father's recommendation, had become chief administrator of the above-mentioned former governor of Brazil, Prince Johan Maurits van Nassau and moved to The Hague, close to the palaces of Johan Maurits. ${ }^{23}$

It was on one of the family visits to Jacob in The Hague that Eva Cohen met Jacob's servant Michiel Verboon, a Christian from a respectable but lower class family. ${ }^{24}$ The legal case files, interviews, and printed pamphlet detail the

Compagnie, ed. Ellinoor Bergvelt, Michiel Jonker, Agnes Wiechmann (Zwolle: Waanders, 2002), 31-45. For offices and warehouses of the voc on Oude Delft since 1631 (the canal on which the Cohen family resided): Verhoeven, De derde stad van Holland, 296. Luc L.M. Eekhout, "De Delftse Kamer van de voc," De stad Delft, 90-94.

On the first Portuguese Jews in The Hague between 1650 and 1670 see Jac. Zwarts, "De Joodse gemeenten buiten Amsterdam," in Geschiedenis der Joden in Nederland, ed. Henk Brugmans and Abraham Frank(Amsterdam: Van Holkema \& Warendorf, 1940), 399-500; Yosef Kaplan, "De joden in de Republiek tot omstreeks 1750: religieus, cultureel en sociaal leven," in Geschiedenis der Joden in Nederland, ed. Hans Blom, David Wertheim, Hetty Berg, Bart Wallet (Amsterdam: Balans, 2017), 144-46.

23 David Franco Mendes, Memorias do estabelecimento e progresso dos judeos portuguezes e espanhoes nesta famosa citade de Amsterdam, ed. Lajb Fuks and Reina G. Fuks-Mansfeld; commentary Benjamin N. Teensma (Assen: van Gorcum,1975), 9o: Jacob was apparently appointed to be his chief accountant and administrator in 1677 (see more in Koninklijk Huisarchief A 4-1455-s.n. documents of Jacob Cohen 1675-1677); Franco Mendes relates to the fact that Jacob's appointment was due to the many services his family had given him and the population of Dutch Brazil, whether Christians or Jews, during the years of siege of Dutch Brazil (1645-1654) by the Portuguese; see on Jacob's whereabouts in New Amsterdam between 1655 and 1658: Samuel Oppenheim, "The Early History of the Jews in New York, 1654-1664," Publications of the American Jewish Historical Society 18 (1909): 19 (1655: request to buy burial ground), 27 (1655: request to Director General and Council of New Netherland for Jews to "travel, reside and trade" in New Netherland), 60 (1658 conflict concerning goods purchased by Cohen to Grytie Maas), 61 (litigation in 1656 for the possession of a canoe with some Dutch merchants), (litigation in 1658 concerning a shipment of tobacco), 75 (request for a Jewish cemetery, 1655); Jacob might have moved to Amsterdam at a later stage, perhaps in 1672 (see above n. 10); for Jacob Cohen as a member of the Honen Dalim society in Amsterdam in 1683 see Wilhelmina Chr. Pieterse, Daniel Levi de Barrios als geschiedschrijver van de Portugees-Israelietische gemeente te Amsterdam in zijn "Triumpho del govierno popular" (Amsterdam: Publikaties van de Gemeentelijke Archiefdienst van Amsterdam, 1968), 124. Jacob apparently died in 1712 and was buried near the Pallaches in the Portuguese Jewish cemetery in Ouderkerk: Emmanuel, "Seventeenth-Century Brazilian Jewry," 62.

24 Michiel Verboon's former employers are mentioned in the pamphlet: Burnet, De ware bekeringe, 5 . He left his last master Jacob with a letter of recommendation and proof of good conduct dated 17 May 1680. Burnet, De ware bekeringe, 5 . 
development of their relationship behind the back of Rebecca Pallache and beyond the borders of the Dutch Republic via Belgium, England, and back. Was Eva and Michiel's a true love story? We know that she signed some of her early letters to him with her own blood, in which she promised never to leave him. ${ }^{25}$ We also know that Eva followed Michiel to Brussels. ${ }^{26}$ However, in the pamphlet, it was suggested that her flight was a means to escape the reach of her controlling mother. ${ }^{27}$ Did religious motives play a role in the events? ${ }^{28}$ And what of Michiel's intentions? Was he in love with Eva or was he hoping for material gain?

The affair, which erupted some time in 1680 , less than ten years after Abraham Cohen's death, most likely came as a shock to Rebecca. However, as the documentation reveals, as matriarch of this wealthy and well-integrated Dutch Sephardic family, she spared no expense to put a stop to what she believed was a ruinous liaison.

The attitude of the Sephardic widow Rebecca Pallache was not exceptional when it came to choosing marriage partners for her children. In the early modern period social-economic motives were most prominent in this respect. In general, marriages were intended to preserve the material wellbeing of the family or, still more, to increase it. The elite, in particular, was very keen to keep wealth within its own circles and enlarge it, if possible, through arranged marriages. ${ }^{29}$ Love was not, typically, a priority in the negotiations. Yet, human

25 NL-HaNA, Hof van Holland entry no. 3.03.01.01, inv. no. 5331. 29, 26 June 1681, interview with Jacobus Bradly.

26 NL-HaNA, Hof van Holland, entry no. 3.03.01.01, inv. no. 5331. 29, testimony of Jeronimus Moens, 19 July 1681: as a guest at the inn in Brussels, Jeronimus witnessed the arrival of Eva Cohen and the intimate way Michiel, also a guest at the same inn, welcomed and embraced her in the early morning hours of 26 or 27 May 1680 . Benjamin Torens, a friend of Michiel, had informed Eva earlier about Michiel's departure for Brussels, after he received his letter from there, ibid., Testimony of Benjamin Torens before notary Jeronimus Stael, The Hague, 16 July 1681. On marriages for the sake of love among non-Jews in the Dutch Republic, mostly in the eighteenth century, see Haks, Huwelijk en Gezin, 138-40.

27 Burnet, De ware bekeringe, 6.

28 If we are to believe Todd Endelman, religious motives in the premodern and early modern world were never the sole reason for conversion: Todd M. Endelman, Leaving the Jewish Fold. Conversion and Radical Assimilation in Modern Jewish History (Princeton, NJ: Princeton University Press, 2015), 47-48.

29 In last wills and other documents of members of the Dutch Sephardic community, we can further read about relatives applying this strict policy, prearranging the marriages of 
nature sometimes intervened and marriages for the sake of love did take place. Some were of a clandestine nature and occurred less frequently in Jewish society, though among the Amsterdam Sephardim, such marriages appear to have increased over the course of the eighteenth century. ${ }^{30}$ Only a herem (ban) imposed by the Jewish community leaders on its members or legal restrictions in the marriage laws in the Dutch Republic could deter such clandestine unions.

To stop her daughter from what she clearly viewed as a bad match, Rebecca Pallache had no recourse but to turn to the Dutch courts, which she did with fervor. As a widow in the Dutch Republic Rebecca Pallache had complete authority over her affairs. ${ }^{31}$ In my previous studies I have shown that even though Sephardic women in Dutch society adhered to the Iberian cultural mores that relegated women to the background, they were, in practice, assertive and enterprising figures inside the home and outside it, just like their Dutch counterparts, albeit somewhat more withdrawn. ${ }^{32}$ Rebecca Pallache offers another example: her last will shows her skill in handling investments in the West Indian Company and maintaining international contacts that extended across

their kin or preventing certain liaisons. See the example the de Prado family as discussed in Tirtsah Levie Bernfeld, "Sephardi Women in Holland's Golden Age," in Sephardi Family Life in the Early Modern Period, ed. Julia R. Lieberman (Waltham, MA: Brandeis University Press, 2010): 193. For material considerations of contracting marriages among non-Jewish families in the Dutch Republic, Haks, Huwelijk en Gezin, 136-40.

On clandestine marriage in non-Jewish society, see Beatrice Gottlieb, The Family in the Western World from the Black Death to the Industrial Age (New York: Oxford University Press, 1993), 84-87, 240; Haks, Huwelijk en Gezin, especially chap. 4; see also Henk Th. M. Roosenboom, Ontvoerd of gevlucht? Religieuze spanningen in Brabant en de zaak Sophia Alberts 1700-1710 (Hilversum: Verloren, 2016); on secret marriage and clandestine betrothal in Jewish society see Jacob Katz, Tradition and Crisis. Jewish Society at the End of the Middle Ages, translated and with an afterword and bibliography by Bernard D. Cooperman (Syracuse, NY: Syracuse University Press, 2000), 119-20; on parents or other family members arranging matches, ibid., $115^{-16}$; see for secret marrriages among the Portuguese Jews in Amsterdam, Yosef Kaplan, "The Social Functions of the Herem in the Portuguese Jewish Community of Amsterdam in the Seventeenth Century," in Dutch Jewish History, ed. Jozeph Michman and Tirtsah Levie [Bernfeld] (Jerusalem: Institute for Research on Dutch Jewry, 1984), 1: 123, and for the eighteenth century, Kaplan, "Moral Panic in the Eighteenth-Century Sephardi Community of Amsterdam:The Threat of Eros," in Dutch Jewry: Its History and Secular Culture, ed. Jonathan I. Israel and Reinier Salverda (Leiden: Brill, 2002), 103-23; Kaplan, "Clandestine Marriage in Amsterdam, Broken Hearts in Hamburg and a Kidnapping in London," [Hebrew] in Tov Elem: Memory, Community and Gender in Medieval and Early Modern Societies, Essays in Honor of Robert Bonfil, ed. Elisheva Baumgarten, Amnon Raz-Krakotzkin, Roni Weinstein (Jerusalem: Mosad Bialik, 2011), 171-90.

31 Ariadne Schmidt, "Vrouwen en het recht. De juridische status van vrouwen in Holland in de vroegmoderne tijd," Jaarboek van het Centraal Bureau voor Genealogie 58 (2004): 27-44. See e.g., Levie Bernfeld "Sephardi Women," 177-222. 
the Atlantic to Suriname, Jamaica, and Martinique. ${ }^{33}$ Other documents reveal her to have been an uncompromising maternal figure who tried to lead her children along the path she and her late husband had set for them.

Apparently, Rebecca had an uneasy relationship with her daughter Eva; both seem to have been strong-willed. ${ }^{34}$ She tried hard to limit her daughter's freedom of movement and, according to the pamphlet, had confined Eva to her room at one point for a period of six months. ${ }^{35}$ Eva's harpsicord teacher Dirck Scholl, who was also the chief organist and carillonist of the Nieuwe Kerk (New Church) in Delft, had once suggested to Rebecca that to improve relations between mother and daughter she should consider giving Eva more freedom of movement like other young Dutch girls in the city. ${ }^{36}$ Rebecca had

33 See inventory Rebecca Pallache 25 September 1685 before Not. F. Tixerandet, sAA 5075, inv. no. 3697 [page numbers unknown]. For Rebecca's network that spanned the Atlantic, and contacts with the chief governor of the Jewish society in Suriname, Samuel Nassy, see her involvement in solving the conflict that arose between her son Mordechay, who was sent to Suriname in 1683 , and the skipper of his boat. The latter refused to hand over Mordechay's goods upon arrival: Meijer, Encyclopaedia Sefardica, 1: 152; Rebecca asked Samuel Nassy to interfere: SAA 5075, inv. no. 3689A, Not. F. Tixerandet, pp. 195-96, 1 October 1683 (power of attorney given by Rebecca Pallache to Samuel Nassy); the Nassy and Cohen families must have known each other through the colonial activities of David Nassy (Samuel's father) and Abraham Cohen: Emmanuel, "Seventeenth-Century Brazilian Jewry," 62; Noah L. Gelfand, "To Live and to Trade. The Status of Sephardi Mercantile Communities in the Atlantic World during the Seventeenth and Eighteenth Centuries," in The Jews in the Caribbean, ed. Jane S. Gerber (Oxford: The Littman Library of Jewish Civilization, 2014), 53-55, 59; Kagan and Morgan, Atlantic Diasporas, 44-49; Bloom, "The Dutch Archives," 15-18; Jonathan I. Israel, Diasporas within a Diaspora. Jews, Crypto Jews and the World Maritime Empires (1540-1740) (Leiden: Brill, 2002), 400-2. On life in Dutch Brazil, see also Charles R. Boxer, The Dutch in Brazil, 1624-1654 (Oxford: The Clarendon Press, 1957).

34 Eva was not entirely innocent. She was reported as having treated her mother with contempt, spitting in her face, and insulting her: NL-HaNA, Hof van Holland entry no. 3.03.01.01, inv. no. 5331. 29, 17 July 1681, interrogation of Dirck Scholl and his wife Jacoba van Heck. For other examples of Eva's irascible character see the testimony of Andries Coster and Anna Cupers (NL-HaNA, Hof van Holland, entry no. 3.03.01.01, inv. no. 5331. 29, 13 June 1681, notary Cornelis Ouwendijck of Delft): her neighbors in Delft; Eva scolded them when they saw how Michiel tried to sneak into Eva's house with her assistance.

35 Burnet, De ware bekeringe, 4-5. History repeats itself: Eva's grandfather Isaac had been confined by his father Joseph in a castle in Purmerend or Purmersteijn because of rebellious behavior: García-Arenal and Wiegers, Samuel Pallache, 220.

36 NL-HaNA, Hof van Holland entry no. 3.03.01.01, inv. no. 5331. 29, 17 July 1681, interrogation of Dirck Scholl and his wife Jacoba van Heck. For more on Dirck Scholl and his influence on musical life in Delft, see Maarten A. Vente, "Aspecten van de Delftse Muziekgeschiedenis," in De stad Delft, 234; Laura J. Meilink-Hoedemaker, "Uurwerken, Luidklokken en Klokkenspellen te Delft," De stad Delft, 240. 
him fired from his post as Eva's music tutor. She also suspected him of influencing Eva toward the Christian faith. ${ }^{37}$

Immediately after Eva's disappearance, Rebecca mobilized a veritable army of laymen and authorities to search for her daughter in Holland and the surrounding countries, ${ }^{38}$ and she was quickly traced to London. ${ }^{39}$ In the lawsuits that followed, Rebecca used every connection she could muster in order to secure her daughter's return. The list of people she sought help from included servants, tutors, tailors, innkeepers, shopkeepers, notaries, and lawyers in Delft, The Hague, Voorburg, Amsterdam, Brussels, Mechelen, and London. ${ }^{40}$ She contacted the burgomasters of Amsterdam, the commissioners of marriage in Delft and The Hague, the Dutch ambassador in England, and rich Sephardic Jews in London, including Michael Levy who was the community's representative to the local authorities. ${ }^{41}$ The list shows the sweep of Rebecca's control over her immediate environment, enabling her to rally assistance from the lower echelons to the highest elite and diplomatic circles. The extent of her contacts should not be surprising given her upbringing in a wealthy, wellconnected family of merchants and diplomats and her marriage to an influential merchant with business and political ties at home and overseas.

It was likely at the urging of Rebecca and other well-connected members of her family that the burgomasters of Amsterdam wrote a letter to the Dutch ambassador in England, which included a formal and explicit accusation of Michiel Verboon "of low-class origin" for seducing and abducting Eva "in an improper and indecent way" on Ascension day 1680. The letter also contained a request for assistance for Moses Cohen (Eva's brother) and Samuel van der Zee (Eva's cousin), who had been sent to England to trace her whereabouts and return the young woman to her mother's care. ${ }^{42}$

37 NL-HaNA, Hof van Holland entry no. 3.03.01.01, inv. no. 5331. 29, 17 July 1681, interrogation of Dirck Scholl and his wife Jacoba van Heck; see also Burnet, De ware bekeringe, 4.

38 As the letter written by the Amsterdam burgomasters relates: NL-HaNA, Hof van Holland entry no. 3.03.01.01, inv. no. 5331. 29, 16 August 1680.

39 In such cases, a couple fleeing was usually detected quickly: Haks, Huwelijk en Gezin, $126-28$.

40 See list in inventory of the file in NL-HaNA, Hof van Holland, entry no. 3.03.01.01, inv. no. 5331. 29.

41 For the position of Michael Levy in London see Hyamson, Sephardim of England, 54, 56, 64,71 .

42 NL-HaNA, Hof van Holland entry no. 3.03.01.01, inv. no. 5331. 29, letter by burgomasters of Amsterdam, written on 6 August 1680. According to the pamphlet, Moses and Samuel stayed for five weeks, from 27 July 168o, in the same inn as the one in which Eva was lodged: Burnet, De ware bekeringe, $7-8$. 
In the case Rebecca brought before the Hof van Holland in The Hague, she accused Michiel Verboon of theft, lechery, and seeking material gain by seducing and illegally marrying her daughter. ${ }^{43}$ The religious issue (it was illegal for a Christian to seduce a Jewess) was reason enough for Rebecca to object to the liaison, ${ }^{44}$ but it would not have mattered since by the time of the trial, Eva had already converted and taken the name Elisabeth.

In the verdict rendered by the Hof van Holland in July 1681 it was decided that Michiel and Eva be denied the right to cohabit. Eva was to live with an honest, well-mannered Reformed family in order to reconsider her position, and her mother would pay for her upkeep. Michiel was not to have any contact

43 Theft: Michiel Verboon was accused of taking the family's jewelry and clothes: NL-HaNA, Hof van Holland entry no. 5331. 29, testimony of Jacobus Duternoy, 26 June 1681; ibid., testimony of Jeronimo Poens, Mechelen, 19 July 1681; in the last will of Rebecca Pallache, Eva is accused of taking jewelry and clothes when she ran away, used by her mother as an excuse, among others, to disinherit her: SAA 5075, inv. no. 3696, Not. F. Tixerandet, 20 August 1685 .

Marriage: Michiel and Eva seem to have married in England via the Church of England on 29 July 1680 (see interview with Jacobus Bradly NL-HaNA, Hof van Holland entry no. 3.03.01.01, inv. no. 5331. 29, 26 June 1681). Apparently, the validity of the marriage was fought in an English court and it was subsequently annulled: Burnet, De ware bekeringe, 7, 12; see also the plea on behalf of Rebecca Pallache by Adriaen Sterrevelt on 15 July 1681, NL-HaNA, Hof van Holland entry no. 3.03.01.01, inv. no. 5331. 29: "hij Verboom met desselfs Eva Cohen naar Engelandt vertrocken aldaer in pretense houwelijcke gansch onwettelijcke wijse heeft begeeven." Almost one year later the couple tried again to register their intended marriage (so-called: "ondertrouwakte") in Delft on 28 June 1681, Doop-TrouwBegraafboeken (henceforth DTв) Delft ARoo14_00132, Ondertrouwboek Gerecht 16751682: 28 June 1681 and in The Hague the next day, 29 June 1681(Haags Gemeentearchief 0377-01, inv. no. $75^{2}$, p. $3^{22}$., 29 June 1681). Remarkable here is the fact that Eva already considered herself as being married to Michiel Verboon: she first signed "Elisabeth Verboon," which is blotted out, and then signed with the name "Elisabeth Cohen; ibid., inv. no. 0351-01, 29 June 1681 [no page number]: the case of marriage registration in The Hague was postponed for forty days by the commissioners of marriage: ibid., inv. no. 777, [no page number], 29 June 1681 .

Lechery: Their marriage in England declared illegal, Rebecca's representative accused Michiel of living with Eva in lechery. A so-called "oneerlijk leven," lechery could be used as another reason for a parent to refuse the marriage of an adult child: Haks, Huwelijk en Gezin, 117-119.

44 Shame and anger were also at stake here, as her daughter had an affair with a Christian: such was also the impression of Michiel's colleagues who warned Michiel that also for religious reasons the mother nor his master would ever agree to accept him as Eva's partner: NL-HaNA, Hof van Holland entry no. 3.03.01.01, inv. no. 5331. 29, 26 June 1681, interview with Jacobus Bradly; ibid., testimony of Jacobus Duternoy, 26 June 1681; see for similar conflicts, but between Protestants and Catholics in Benjamin J. Kaplan, Divided by Faith. Religious Conflict and the Practice of Toleration in Early Modern Europe (Cambridge, MA: The Belknap Press of Harvard University Press, 2007), 268-76. 
with Eva. ${ }^{45}$ The verdict seemed a fair compromise to Rebecca who viewed it as a reasonable starting point for her plan to return Eva to the family fold. Rebecca's partial victory, however, was short-lived. Michiel not only continued to visit Eva, ${ }^{46}$ but the couple appealed to the Hoge Raad and in 1684 , after a lengthy trial, Michiel and Eva were granted permission to proceed with their intended marriage. Rebecca had lost her case.

Rebecca had done all she could to restore her daughter. She had reached out to as many people as she was able at home and abroad. ${ }^{47}$ But also aware of the need to preserve the rest of her family, at the height of the affair, in 1681, she moved from Delft to Amsterdam. Her decision to relocate might have been motivated by her fear that the remainder of her family could fall outside influences as Eva had, and she preferred to raise her other children closer to organized Portuguese Jewish life, away from the dangers of crossing borders into the Christian world. ${ }^{48}$

\section{Eva Cohen in between Judaism and Christianity}

Eva grew up in a home that included instruction in the basic tenets and observance of normative Judaism. According to the testimony of Dirck Scholl and his wife at the trial in The Hague, Eva had expressed feelings of guilt when she gave a monetary donation to a sexton of the New Church on a visit to the

45 Rebecca suggested such a proposition in her plea of 15 July 1681: NL-HaNA, Hof van Holland entry no. 3.03.01.01, inv. no. 5331. 29, 15 July 1681. Apparently her suggestion was taken over by the Hof: ibid., verdict Hof van Holland, 31 July 1681. A similar policy was followed in the case of Elisabeth de Flines, see Bosman, Elisabeth de Flines, 97: Elisabeth was to stay in her father's home (not somewhere else as in Eva's case; the court apparently was not going to put back Eva into a Jewish home after her conversion) for three months in order to give her time to consider her future without having any contact with her lover; if she persisted in her intentions to marry him, she was to be allowed to proceed with the marriage.

46 NL-HaNA, Hof van Holland, entry no. 3.03.01.01, inv. no. 284, 3 December 1681.

47 See for example the interview with Jeronimo Poens from Mechelen, guest at the inn called Court of Spain in Brussels, 19 July 1681; and also the interview with the innkeeper of Court of Spain Francois Valentijn and his wife Petronella Verlijden in Brussels, 8 July 1681: NL-HaNA, Hof van Holland entry no. 3.03.01.01, inv. no. 5331. 29.

48 Eva relates to her mother's move from Delft to Amsterdam, which she regrets, in an undated letter: NL-HaNA, Hof van Holland, entry no. 3.03.01.01, inv. no. 5331. 29, undated letter Eva Cohen. The extent of Rebecca's desire to ban conflicts from her family is evident in her last will, in which she admonished her children to show each other brotherly love: last will of Rebecca Pallache: SAA 5075, inv. no. 3696, Not. F. Tixerandet, 20 August 1685: "aanbevolen $[\ldots]$ een onderlinge broederlijke liefde." 
church on a Saturday (Fig. 8.3), the Jewish Sabbath. ${ }^{49}$ The Jewish dietary laws appear to have been kept in Eva's home and among her extended family. On their expedition to England in order to retrieve her, Eva's brother and cousin were apparently provided with kosher food. ${ }^{50}$ From Scholl's interrogation, we also learn that Eva was aware that she was eating forbidden food when she dined at his home. ${ }^{51}$ In one of Eva's letters that was entered in evidence at the trial she had asked for sweets [?] for Purim, which showed that she was familiar with the observance of Jewish festivals and rituals. ${ }^{52}$ Further proof of Eva's family's upholding of Jewish tradition was their observance of the Jewish mourning rituals at the death of Eva's brother Joseph, in 1680: the family sat shiva "in the Jewish manner" in the house of relatives on Verversgracht in Amsterdam. ${ }^{53}$ From the wording of the text that appears on his tombstone, Joseph most likely belonged to the Tipheret Bajurim society, an Amsterdam study circle for young men from rich Portuguese families. ${ }^{54}$ Jacob, Eva's oldest brother was active in the Amsterdam Portuguese community's charitable Honen Dalim society. 55

49 NL-HaNA, Hof van Holland entry no. 3.03.01.01, inv. no. 5331. 29, 17 July 1681, interrogation of Dirck Scholl and his wife Jacoba van Heck.

5o For kosher food being delivered in London see Burnet, De ware bekeringe, 8; Eva's brother Mordechay was supplied with special food (e.g., meat) as well on his journey to Suriname in 1683: Meijer, Encyclopaedia Sefardica, 1: 152. On the other hand, Abraham Cohen attended dinners at the West Indian Company headquarters in Amsterdam and apparently was not all that strict in keeping kosher outside of the house or when traveling abroad, Daniel M. Swetschinski, Reluctant Cosmopolitans, The Portuguese Jews of SeventeenthCentury Amsterdam (London: The Littman Library of Jewish Civilization, 2000), 214 and n. 161. Hulshof, "Een Duitsch econoom," 77.

51 NL-HaNA, Hof van Holland entry no. 3.03.01.01, inv. no. 5331. 29, 17 July 1681, interrogation of Dirck Scholl and his wife Jacoba van Heck.

52 NL-HaNA, Hof van Holland, entry no. 3.03.01.01, inv. no. 5331. 29: letter Eva Cohen, 4 February 1681: in the document it is difficult to read what exactly she is requesting.

53 NL-HaNA, Hof van Holland, entry no. 3.03.01.01, inv. no. 5331. 29, testimony of Samuel van der Zee and Nathan Samuels, Sara Pallache and Abraham Nathans before Notary Nicolaes Hemmich in Amsterdam, 18 June 1681. They relate, among others, to the fact that Eva's brothers Jacob, Moses and Mordechay (Marten) were just returning from the cemetery in Ouderkerk and that the family observed the mourning period according to Jewish custom ("volgens de Jootsche manieren").

54 For Joseph Acohen who died 30 Adar II 5440 see the Hebrew text on his grave: https:// www.dutchjewry.org/phpr/amsterdam/port_isr_gem_burials/amsterdam_port_isr_gem_ burials_view.php?editid1 $=5595$. On the Tipheret Bajurim society, see Levie Bernfeld, Poverty and Welfare, $128-30$.

55 Pieterse, Daniel Levi de Barrios, 124; see more on this society in Levie Bernfeld, Poverty and Welfare, 122, 125-27, 131. 


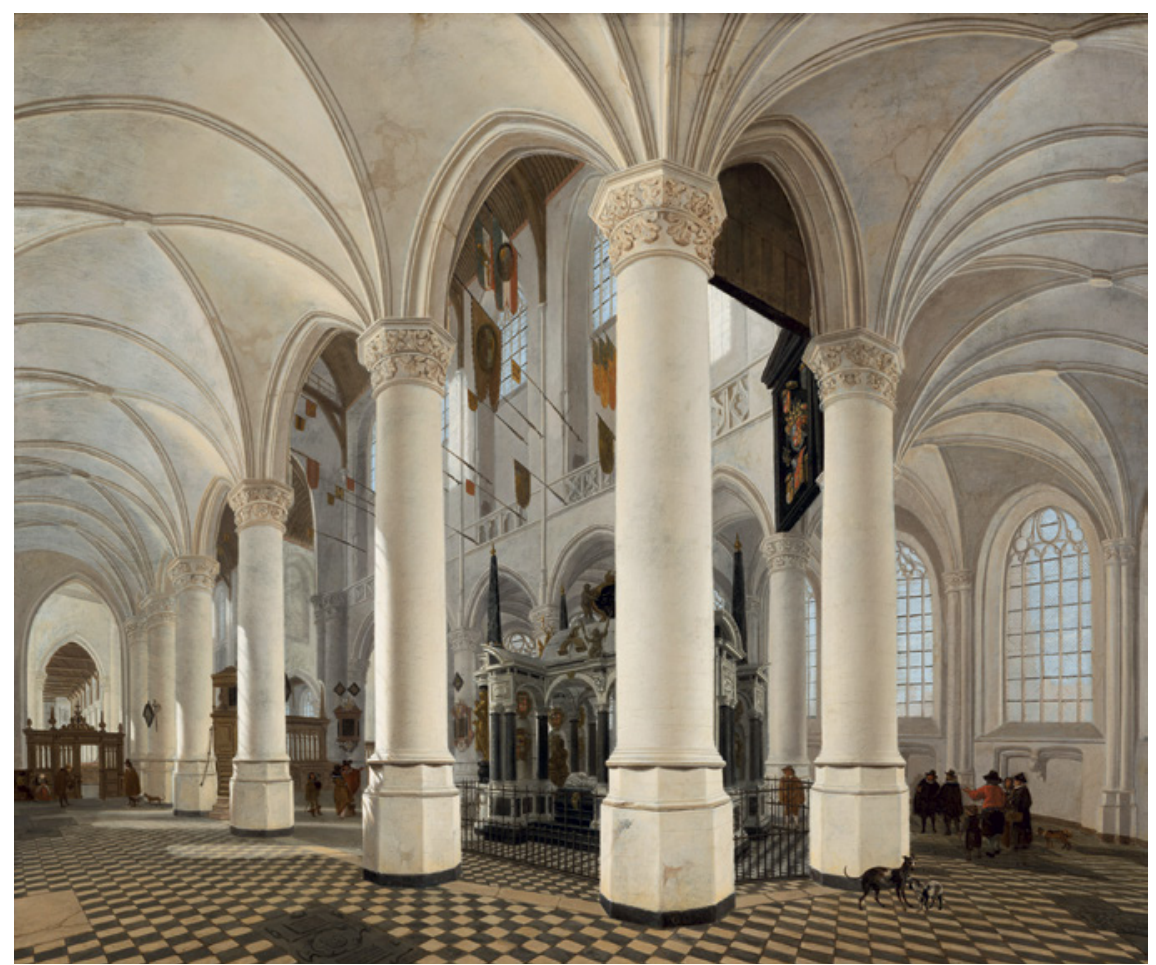

FIGURE 8.3 Gerard Houckgeest, New Church in Delft, 1651, Mauritshuis, The Hague

In Rebecca's last will there were no gifts to be distributed among the Portuguese poor or any public or private Portuguese Jewish organization, ${ }^{56}$ which is consistent with the loose connection of the family to organized Jewish life in general and to the Amsterdam Portuguese community in particular, already noted at the beginning of this study. Yet, as was also mentioned above, Rebecca did give the sum of two hundred guilders to the Amsterdam Portuguese community in 1671 for escabot prayers (prayers for the repose of the soul of the dead) to be recited for her husband "Abraham Cohem do Brazil."57 Also, among the contents in her home was a book of Flavius Josephus, apparently in Hebrew. ${ }^{58}$ In fact, more than twenty years earlier, in 166o, Abraham Cohen had given instructions to the Amsterdam publishing house of Uri Phoebus Halevi to print four thousand copies of "Josephus" in Hebrew, to be delivered to him

56 See last will of Rebecca Pallache: SAA 5075, inv. no. 3696, Not. F. Tixerandet, 20 August 1685 .

$57 \quad$ See above n. 9 .

$5^{8}$ See inventory Rebecca Pallache, above n. 33 . 
by no later than 31 June 1661, most likely for the purposes of trade. ${ }^{59}$ The copy found in Rebecca's house must have been from that order.

During their lifetimes, Abraham and Rebecca signed various documents in Hebrew, ${ }^{60}$ which could be seen as evidence of the importance of their Jewish identity. Furthermore, the inscriptions on their gravestones at the Bet Haim cemetery in Ouderkerk are in Hebrew, which was not a common phenomenon. ${ }^{61}$ Finally, Rebecca's recommendation to her children in her last will and testament that they have fear of God is proof of her sincere belief in her faith. ${ }^{62}$ In all, there is enough evidence to suggest that Eva was surrounded by a Jewish atmosphere at home and that the family lived by the rules of normative Judaism.

Still, the inventory of the contents of Rebecca Pallache's house, which was drawn up after her death in 1685 , includes few material pieces of a Jewish connection. ${ }^{63}$ There were no ceremonial objects explicitly mentioned as such, even though the silver and copper candelabrums on the list could have been used for lighting candles on Sabbaths and holidays. The "paasbrood" (matsot) mentioned in the inventory suggests that Jewish holidays were celebrated at her home as we have surmised earlier from Eva's remarks on Purim. ${ }^{64}$

In all other aspects, the contents of Rebecca Pallache's house contained objects that could have been found in the home of any member of Dutch elite society: silver objects decorated with coats of arms, paintings-about fifty in all, more than the average in a Dutch residence of the times-including landscape, mythological, vanitas, and genre scenes, family portraits, and portraits of emperors and local rulers, like Prince Maurits. ${ }^{65}$ The Spanish chairs,

59 Meijer, Encyclopaedia Sefardica, 1: 152.

6o For Cohen's signing in Hebrew of the imposta regulations as well as the statutes of the Portuguese Jewish community in Recife, Brazil, see SAA 334, inv. no. 1304, p. 11, 5409, 15 Kislev; Wiznitzer, Jews in Colonial Brazil, 137. Rebecca Pallache signed her last will with her Hebrew first name (SAA 5075, inv. no. 3696, Not. F. Tixerandet, p. 294, 20 August 1685). Her father Isaac Pallache could have instructed his children into Hebrew (García-Arenal and Wiegers, Samuel Pallache, 222-23; Hugo de Groot, Remonstrantie, 30, n. 57). Then, members of the Pallache and Cohen families might traditionally have learned Hebrew at an early age, both originating from Jewish worlds, i.e., North Africa and the Levant (Emmanuel, "Seventeenth-Century Brazilian Jewry," 49, 61: Abraham Cohen is described here as a Sephardic Levantine Jew).

61 See above n. 11 .

62 See last will of Rebecca Pallache: SAA 5075, inv. no. 3696, Not. F. Tixerandet, 20 August 1685 , "aanbevolen des vreese Godes."

63 See inventory Rebecca Pallache, above n. 33.

64 Ibid.

65 See for example the painting by Michiel van Mierevelt in the Stedelijk Museum "Het Prinsenhof". 
Spanish lace, Turkish table carpet, East Indian chest, silken bedcover, and Delft porcelain that completed the inventory hint at the international DutchSephardic nature of this household.66

The Cohen Pallache's may have been a Jewish home, but it was situated in Delft, where there was no Jewish community to speak of at the time. The Reformed churches, just a few steps from Rebecca's house on the affluent Oude Delft canal were a lure for Eva and helped to spark her interest in Christianity (Fig. 8.4) ${ }^{67}$ Stories about the conversion of her grandfather, and the baptisms of her mother, aunts, and uncles, could also have stimulated her interest in the Christian faith. As a teenager, she would have known the story of her aunt Hester Pallache who had converted to Christianity along with her husband Simon Samuel, but had their sons circumcised nevertheless. The governors of the Reformed Church, upon hearing about the circumcision, summoned the parents. Hester explicitly blamed "her sister" (could the sister have been Rebecca?), but the church nevertheless placed the parents under strict supervision. ${ }^{68}$

66 Levie Bernfeld, "Matters Matter: Material Culture of Dutch Sephardim," Studia Rosenthaliana 44 (2012): 203-13. In the middle of the seventeenth century forty to fifty thousand paintings were hanging in four thousand Delft houses, which comes to an average of ten per Delft house, while Rebecca Pallache owned around fifty paintings, far above average. On the basis of 1,224 Delft inventories around 1679, fourteen percent of these paintings were of religious themes; landscapes counted for forty-one percent; still lives for seventeen percent; portraits for fifteen percent (portraits of stadholders, monarchs, admirals and preachers were popular in the middle of the seventeenth century); genre paintings for seven percent; allegory two and a half percent; in the inventory of Rebecca Pallache, the subject category of the paintings are not easily readable especially since the paper was burned on the sides; we could identify twenty-seven paintings with specific subjects out of which no religious themes were to found, yet twenty-six percent were genre scenes, twenty-two percent were allegories, nineteen percent were landscapes, eleven percent were portraits, another eleven percent were maps, and seven percent were mythological subjects; see further John Michael Montias, Artists and Artisans in Delft. A Socio-Economic Study of the Seventeenth Century (Princeton, NJ: Princeton University Press, 1982), chap. 8. One son, Mordechay, is described as the painter of two of the paintings: "nog twee schilderijen zijnde een oud mannetje en vrouwtje door Mordehay Cohen zelf geschilderd."

67 One of Eva's letters mentioned the address in Delft: "Mevrouw Cohen op het Oude Delft het tweede huys van het Begijnhof" (NL-HaNA, Hof van Holland, entry no. 3.03.01.01, inv. no. 5331. 29: Letter Eva Cohen, 4 February 1681); for young people being lured to other religious denominations, Benjamin Kaplan, Divided by Faith, 273-74.

68 Hester explained how she was severely threatened, wording it thus: "seer quaelick [...] met smadelicke benaemingen en harde bedreijgingen." For the supervision the Reformed Church placed on the couple who lived on the Nieuwe Keizersgracht in Amsterdam, see SAA 376, inv. no. 1, no. 12, pp. 317 and 319, 15 June and 6 July 1673; ibid., no. 13, p. 45, 2 August 1674; see also Roodenburg, Onder Censuur, 188-189, and Jac. Zwarts, "Assimilatiepogingen 


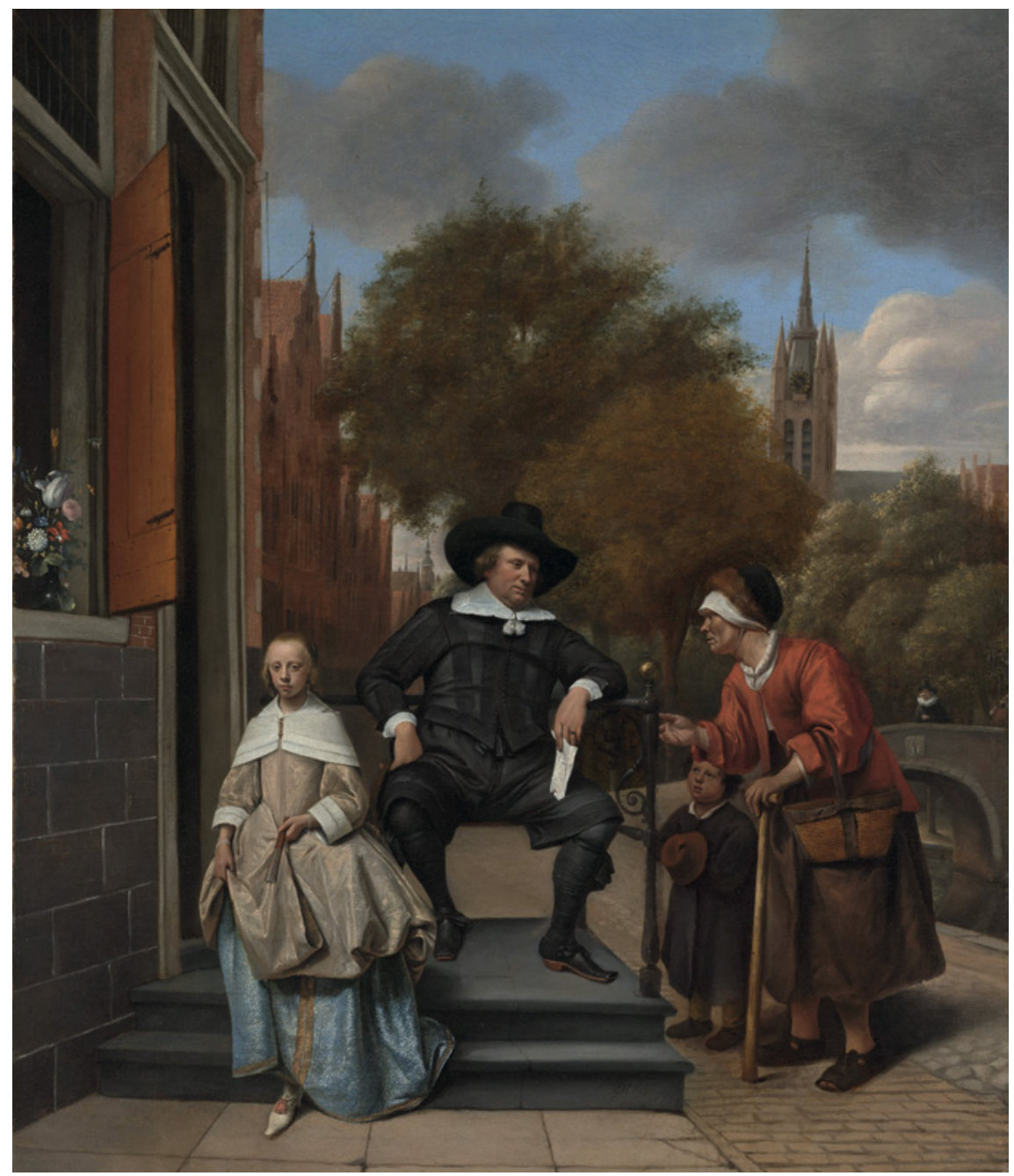

FIGURE 8.4 Jan Havicksz. Steen, Adolf and Catharina Croeser, known as "The Burgomaster of Delft and His Daughter," 1655, Rijksmuseum, Amsterdam. Eva Cohen and her family lived along this same canal, "Oude Delft," nearby the Old Church visible in the background.

Given Eva's rebellious nature, her own attraction to Christianity may have been a reaction to her mother's obvious devotion to Judaism, and a way to escape

van overheidswege," in Hoofdstukken uit de Geschiedenis der Joden in Nederland, ed. Jac. Zwarts (Zutphen: W.J. Thieme, 1929), 139: Apparently, Hester Pallache did receive welfare from the Reformed Church following her conversion, which must have taken place before 1669 . 
her control. ${ }^{69}$ She was reported to have spoken disrespectfully about Judaism in the company of people outside of her family, saying she had no inclination to marry a Jew and hoped one day to eat non-kosher food like shrimps. But, being aware of the sensitivity of the subject among her family, she kept her thoughts secret from them..$^{70}$

It was not difficult for Eva to mix with Gentile circles in Delft through daily interactions with servants, shopkeepers, and tutors. ${ }^{71}$ Eva's music tutor Dirck Scholl taught her at home, but Eva apparently also visited his house, from where he took her to the New Church to hear the playing of the organ. At church, she would have listened to the sermons, heard the reading of the New Testament, the singing of the psalms, and seen the performance of various ceremonies. ${ }^{72}$ Scholl apparently discussed the New Testament with her in the presence of her siblings, and Eva warned him against this fearing that word would get back to her mother. ${ }^{73}$ During his interrogation in court, Scholl said that he was not aware that Eva had deliberately come to him to learn about the Christian religion. Yet, despite Scholl's credulousness regarding Eva's visits to his home and the church, these outings did awaken her interest in the Christian religion. ${ }^{74}$ In fact, according to the pamphlet, Eva enjoyed reading the New Testament and had become convinced that Jesus was the savior. She had, since then, declared that she wanted to embrace Christianity and rejected Judaism. ${ }^{75}$ It is possible that she was in touch with the vicar of the New Church, but the latter had declined to answer any questions in the matter. ${ }^{76}$

Eva fled from Brussels to London in May 1680 and converted to Christianity in London on 10 October 1680. According to the pamphlet, the clergy in London allowed some time to pass before her conversion in order to test the sincerity of

69 Elisheva Carlebach also shows that conversion from Judaism might have had to do with rebellion against the environment in which the converts were brought up: Elisheva Carlebach, Divided Souls: The Convert Critique and the Culture of Ashkenaz, 1750-180o (New York: Leo Baeck Institute, 2003), 8.

70 NL-HaNA, Hof van Holland entry no. 3.03.01.01, inv. no. 5331. 29, 17 July 1681, interrogation of Dirck Scholl and his wife Jacoba van Heck.

71 Ibid.

72 Ibid.

73 Ibid.

74 Ibid.

75 Burnet, De ware bekeringe, 4-5. If we are to believe the report in the pamphlet, Scholl gave her the New Testament: ibid.

76 For the questions addressed to the vicar Hansselaer see NL-HaNA, Hof van Holland entry no. 3.03.01.01, inv. no. 5331. 29, 14 July 1681: the vicar asked for time to think about the questions but did not make the time to meet the clerk in order to give the answers. Thus it is not known whether he had ever been in the house of Eva Cohen to inquire about her inclination to convert; see also Burnet, De ware bekeringe, 6. 
her desire, in the interim offering her protection at the home of a pastor. ${ }^{77}$ Eva's decision to convert was not exceptional. Other Jews converted to Christianity in the early modern period, causing scandals and uproar in both the Jewish and Gentile communities. ${ }^{78}$ Though Eva did not return to Judaism after her conversion, the language she uses betrays the fact that she did not completely leave the Jewish fold either. ${ }^{79}$

Little is known about the education and upbringing of girls in the Western Sephardic milieu in the early modern period. The story of Eva Cohen, however, offers an opportunity for a closer look at the rearing of a daughter in an elite Sephardic family. In the Portuguese community in the Dutch Republic, there were no official religious or secular educational institutions for girls. Sephardic girls from less fortunate families were thus often illiterate. ${ }^{80}$ Girls from wellto-do families, however, generally received private tutoring at home. ${ }^{81}$ Eva was taught to read, write, and speak Dutch and received instruction in the basic laws of Judaism. She also received private music lessons from a famous musician as noted above.

Portuguese girls like Eva were closely supervised. The statutes of the Amsterdam Portuguese community and various notarial deeds contain decisions limiting the freedoms of the community's female members. They were to remain at home and were not to go out unaccompanied, not even to the synagogue, where they were explicitly prohibited from going in the evenings

77 Burnet, De ware bekeringe, 13; for protection offered to youngsters encouraged to convert, Benjamin Kaplan, Divided by Faith, 273-74; for supervising and inspection of the behavior of candidates for conversion, ibid., 277-78; Roodenburg, Onder Censuur, 124-41.

78 See for Amsterdam the cases of conversion from Judaism to the Reformed Church mentioned in Roodenburg, Onder Censuur, 186-89 as well as Levie Bernfeld, Poverty and Welfare, 215-16, 221, 477-78, n. 403; Carlebach, Divided Souls, 5; Benjamin Kaplan, Divided by Faith, 268-93.

79 After her conversion she continued to talk about Jewish festivals and tradition: see as cited above her letter dated 4 February 1681: NL-HaNA, Hof van Holland, entry no. 3.03.01.01, inv. no. 5331. 29. Converts in the early modern world tend to be part of an ambiguous group, often navigating between different religious denominations: Benjamin Kaplan, Divided by Faith, 291-92, 313, 315-16. Endelman, Radical Assimilation in English Jewish History, 1656-1945 (Bloomington: Indiana University Press, 1990), 9-33.

80 Levie Bernfeld, Poverty and Welfare, 100-1.

81 Ibid., 98. 
and early mornings with the exception of certain holidays. ${ }^{82}$ On visits to The Hague and Amsterdam, Eva was escorted by her siblings.

Despite the limitations placed on their movement by the communal religious authorities, the lifestyle of wealthy Sephardic women was unconstrained and privileged in other ways. The relatively tolerant society of which the Dutch Republic was an example, allowed Eva, a Jewess, freedom of movement, which enabled her contact with the wider world. ${ }^{83}$ Affluent Sephardic women were attended by servants in and outside of the home, including to and from the synagogue. ${ }^{84}$ When Eva traveled to Brussels in order to meet Michiel, a servant accompanied her and carried her baggage. ${ }^{85}$ Sephardic women were also known for their fashionable dress and lack of restraint in this regard, which the rabbis and communal elders often decried. ${ }^{86}$ Indeed, Eva was reported as wearing expensive clothing and jewelry at the inn in Brussels where she joined Michiel after she fled from home. ${ }^{87}$

82 Levie Bernfeld, "Sephardi Women," 182; Levie Bernfeld, "Religious Life among Portuguese Women in Amsterdam's Golden Age," in The Religious Cultures of Dutch Jewry, ed. Yosef Kaplan and Dan Michman (Leiden: Brill, 2017): 95. Also in Christian milieus of the seventeenth century, upbringing of children was often strict and harsh. See for example Roosenboom, Ontvoerd of gevlucht, $54-58$.

83 Benjamin Kaplan, Divided by Faith, 293.

84 At least one maid in Delft was mentioned in the sources who almost discovered Michiel sneaking into Eva's room in Delft: NL-HaNA, Hof van Holland entry no. 5331. 29, testimony of Jacobus Duternoy, 26 June 1681; for servants in the synagogue, SAA 334, inv. no. 19, p. 165/80, undated [most likely 18 Elul 5401]; see also on servants, Levie Bernfeld, "Sephardi Women," 188. See also Levie Bernfeld, "Masters, Maids and Mistresses: Aspects of Domestic Life among the Portuguese Jews in the Seventeenth-Century Dutch Republic," in Sephardische Perspektiven: Viertes Jahrbuch des Selma Stern Zentrums Jüdische Studien Berlin-Brandenburg, ed. Sina Rauschenbach (Berlin/Leipzig: Hentrich \& Hentrich, forthcoming: 2019).

85 NL-HaNA, Hof van Holland entry no. 3.03.01.01, inv. no. 5331. 29, testimony of Jeronimo Poens, Mechelen, 19 July 1681. The baggage apparently also included clothes for Michiel. That fact was confirmed by Rebecca who noted in her last will that Eva took several pieces of jewelry with her as well as clothes when she ran away with Michiel in 1680: last will of Rebecca Pallache: SAA 5075, inv. no. 3696, Not. F. Tixerandet, 20 August 1685.

86 Levie Bernfeld, "Religious Life," 94-95.

87 At least her dresses made quite an impression on the inn's guests in Brussels, when she arrived to join Michiel in that city. NL-HaNA, Hof van Holland, entry no. 3.03.01.01, inv. no. 5331. 29, testimony of Jeronimo Poens, 19 July 1681. 
During the period of Eva's stay in London, between the years 1680 and 1681, Eva and her mother exchanged a series of letters. ${ }^{88}$ Of the four surviving letters from Eva, two were written during the summer of 1680 , before her conversion. While this correspondence makes clear that Rebecca intended to maintain contact with her daughter, it also appears that she sent Eva money in an attempt to lure her home. ${ }^{89}$ She used that tactic again in October 1684 before the verdict of the Supreme Court, when she transferred a monetary gift to Eva "out of motherly love and tenderness." 90

The language of Eva's letters is ambiguous. On the one hand, she shows remorse for having caused her mother pain and expresses her love for her. Explaining that she acted out of desperation, she promises to be obedient ${ }^{91}$ and to return to the family and to her mother's supervision. ${ }^{92}$ She does not relate to the events surrounding her running away, dismissing them as unimportant. ${ }^{93}$ On the other hand, without mentioning the name of Michiel Verboon, Eva tries to justify her desire to marry someone of a lower class by offering comparisons of a king's daughter marrying a count and of a princess marrying a nobleman. ${ }^{94}$

The letters suggest that Eva is torn between her love for Verboon and loyalty toward her mother and family. She admits her joy at receiving her mother's letters and writes of her great love for her siblings, especially for her sister, who was then around eight years old, ${ }^{95}$ and her brother Jacob, ${ }^{96}$ and of dreaming of her brother Joseph, who had died a few months before. In this respect, she apparently felt the growing isolation and alienation that could overcome

88 Burnet, De ware bekeringe, 7. Eva's brother Moses who was sent to London to try to bring her back acted as courier for one of Rebecca's letters in which she apparently asked that Eva leave Michiel and return home.

89 See letter written by Eva Cohen, 4 February 1681, reacting to her mother's letter dated 28 January.

90 Last will of Rebecca Pallache: SAA 5075, inv. no. 3696, Not. F. Tixerandet, 20 August 1685: "niettegenstaande de comparante uit moederlijke teerheid en mededogenheid bewogen zijnde alsoo Eva Cohen haar dochter tot uiterste armoede vervallen was en anders niet bestaan konde aande sulx nog bij seeker verdrag of accoord voor mij notaris en zekere getuigen op 9 oktober 1684 de somme heeft gegeven van 3140 guldens."

91 NL-HaNA, Hof van Holland, entry no. 3.03.01.01, inv. no. 5331. 29, Letter Eva Cohen, 23 August 1680; Letter Eva Cohen, 4 February 1681.

92 Ibid., Letter Eva Cohen, 7 August 168o; Letter Eva Cohen, February 4, 1681.

93 Ibid., Letter Eva Cohen, 7 August 1680.

94 Ibid., Letter Eva Cohen, 13 August 1680.

95 Ibid., Letter Eva Cohen, 4 February 1681. She even warns her mother where she must especially watch out for her sister: in the garden and to keep her from going near the well.

96 Ibid., Letter Eva Cohen, 13 August 168 o. 
converts on the verge of leaving behind a close-knit family and familiar environment. ${ }^{97}$

Eva's efforts to soothe her mother, ${ }^{98}$ could have been part of a strategy intended to stop her mother from taking legal steps to disinherit her, ${ }^{99}$ and at the same time maintain her relationship with Verboon. Eva's intention to convert is not addressed in her letters or in her mother's. Perhaps her conversion is the "matters" she mentions in the letters, which, aware of the sensitivity of the subject, she cautiously prefers to discuss with her mother in person.

The letters between Eva and her mother were written in Dutch. Eva and Michiel Verboon must also have communicated in Dutch. ${ }^{100}$ From her letters we know that Eva was trying to learn English and had even hired a private teacher for that purpose soon after she arrived in London. ${ }^{101}$ In one of her letters, Eva uses the Hebrew terms "Poeriem" and "Vesalom," but writes these in Latin characters. ${ }^{102}$ We cannot be certain whether she knew how to write Hebrew.

\section{Michiel Verboon's Motives}

Michiel Verboon, a servant in the employ of Jacob Cohen, actively courted Eva Cohen, the sister of his wealthy master. ${ }^{103}$ He wrote her letters, brought

97 Ibid., Letter Eva Cohen, 13 August 1680; on isolation of converts from Judaism, Carlebach, Divided Souls (2003), 10, 19; Endelman, Leaving the Jewish Fold, 34-37.

98 She asked her mother whether she might stay in England in order to learn more English (Letter Eva Cohen, 7 August 1680 NL-HaNA, Hof van Holland, entry no. 3.03.01.01, inv. no. 5331. 29) and to send her Dutch cheese or fine linen, since she is in need of those products and they are either not to be found in England or very expensive (ibid., Letter Eva Cohen, 4 February 1681).

99 On widows' last wills and inheritance in Dutch law, see Schmidt, Overleven na de dood. Weduwen in Leiden in de Gouden Eeuw (Amsterdam: Prometheus/Bakker, 2001), 113-20.

100 One witness from Mechelen told his interviewer that Eva spoke in Dutch: "op zijn Hollands" (NL-HaNA, Hof van Holland, entry no. 3.03.01.01, inv. no. 5331. 29, testimony of Jeronimo Poens, Mechelen, 19 July 1681); on the exchange of letters between Eva and Michiel see below n. 104.

101 NL-HaNA, Hof van Holland, entry no. 3.03.01.01, inv. no. 5331. 29, letter Eva Cohen, 7 August 1680.

102 NL-HaNA, Hof van Holland, entry no. 3.03.01.01, inv. no. 5331. 29, letter Eva Cohen, 4 February 1681. Among Sephardim, the term "Vesalom" commonly appears at the end of documents: see for example the petition of Ester Fonseca de Liorne in Levie Bernfeld, Poverty and Welfare, 461, n. 245 .

103 Jacobus Duternoy confirmed the fact that while he was a servant with Jacob Cohen, Michiel Verboon told him he was trying to lure Eva Cohen: NL-HaNA, Hof van Holland entry no. 5331. 29, testimony of Jacobus Duternoy, 26 June 1681. 
her gifts, and sneaked visits with her in her home in Delft and on trips to The Hague. ${ }^{104} \mathrm{He}$ insisted that he was in love with Eva. ${ }^{105}$ Rebecca's mother, however, was convinced that Michiel's interest was not Eva, but her fortune. ${ }^{106}$ Supporting her intuition were remarks of friends of Michiel interviewed for the trial. For example, on a trip from London to Rotterdam, Michiel had told his good friend Benjamin Torens that by courting Eva he tried to make his fortune. He told his colleague Jacobus Bradly likewise. ${ }^{107}$ He maintained that he was even willing to embrace the Jewish faith for such a purpose. ${ }^{108} \mathrm{He}$ also said that he was waiting for Eva's mother to die so he could cash in the inheritance. ${ }^{109}$

In an attempt to impress the Cohen Pallache family Michiel went so far as to devise a ruse involving a sick uncle on his deathbed who was about to leave him a fortune. While accompanying his master Jacob Cohen to the shiva for his

104 Presents: Michiel bought special gifts for her like ribbons and sweets (see interview with Jacobus Bradly: NL-HaNA, Hof van Holland entry no. 3.03.01.01, inv. no. 5331. 29, 26 June 1681). According to Aernout van Woestinghove, Michiel frequently arrived late at night at Aernout's house where Eva was staying, under the pretext of being sent by his master Jacob Cohen, bringing her sweets and ribbons (NL-HaNA, Hof van Holland, entry no. 3.03.01.01, inv. no. 5331. 29, before notary Jeremias Stael, The Hague 16 June 1681). Michiel also asked Jacobus Duternoy for money to buy Eva presents (NL-HaNA, Hof van Holland entry no. 5331. 29, Testimony of Jacobus Duternoy, 26 June 1681).

Letters: Jacobus Bradly was one of the intermediaries who acted as a courier for their letters (NL-HaNA, Hof van Holland entry no. 3.03.01.01, inv. no. 5331. 29, 26 June 1681, interview with Jacobus Bradly).

Waiting in front of her house: A tailor and his wife claimed they had seen Michiel waiting across from Eva's house in Delft. He made signs to Eva who was watching from the window. Then he moved across the bridge over the water to talk to her, after which he was let into the house by her through the window (NL-HaNA, Hof van Holland entry no. 5331. inv. no. 29, Testimony of Andries Coster and Anna Cupers before notary Cornelis Ouwendijck of Delft: NL-HaNA, Hof van Holland, entry no. 3.03.01.01, inv. no. 5331. 29, 13 June 1681).

Michiel took Jacobus Duternoy to Delft so Michiel could bring Eva to him while she was standing in a grocery shop across the street from her house (NL-HaNA, Hof van Holland entry no. 5331. 29, Testimony of Jacobus Duternoy, 26 June 1681).

Spending nights together: Michiel had told Jacobus Duternoy he managed to sneak into Eva's room at her mother's house. Also, he managed to get Eva to stay in Jacob's house in the room where her brother Moses was supposed to stay and thus managed to see her in her room. He insisted that it be kept a secret (NL-HaNA, Hof van Holland entry no. 5331. 29, testimony of Jacobus Duternoy, 26 June 1681). Michiel deceived his master on more occasions with false letters in order to get close to Eva Cohen (ibid.).

105 NL-HaNA, Hof van Holland entry no. 3.03.01.01, inv. no. 5331. 29, 26 June 1681: interview with Jacobus Bradly.

106 Ibid., plea of Adriaen van Sterrevelt on behalf of Rebecca Pallache, 15 July 1681.

107 Ibid., testimony of Benjamin Torens before notary Jeronimus Stael, The Hague 16 July 1681. For the interview with Jacobus Bradly see ibid., 26 June 1681.

108 Ibid., testimony of Jacobus Duternoy, 26 June 1681.

109 Ibid., interview with Jacobus Bradly, 26 June 1681. 
and Eva's brother Joseph at a Pallache family member's home in Amsterdam, Michiel arranged for a servant to deliver a letter to him on behalf of this imaginary rich uncle. This make-believe uncle was summoning Michiel to his home in Voorburg in order to bestow upon him a large sum. Michiel asked his master for permission to leave in order to attend the signing of the last will. Michiel naively assumed that the Pallache Cohens would be impressed by his impending inheritance, and thereby increase his chances of marrying Eva. ${ }^{110}$ To people he met on his travels to Brussels and London, he claimed he worked as a cornet (officer in the army), producing as proof an orange scarf with silver fabric from his travel bag. He also showed off gold rings studded with diamonds and blue stones, apparently taken from, or given to him by, Eva. ${ }^{111}$

In many respects, Michiel was a simple dreamer and a highflyer, yet he was also stubborn and brave. Supported by his lover, he was ready to appeal his case to the highest court, though both he and Eva likely knew that their chances of success were relatively good.

Eva Cohen and Michiel Verboon spent four years (1680-1684) battling for recognition of their relationship and for their marriage to be legalized, which it finally was following an appeal of the decision of the Hof van Holland to the Supreme Court of the Dutch Republic. In July 1684, the Supreme Court granted the couple the right to marry. ${ }^{12}$ Fearing an outcome where part of her family's wealth would have to be surrendered to the servant, Rebecca Pallache took the unusual step of disinheriting her daughter already in $1682 .{ }^{113}$ She reiterated her

110 Ibid., testimony of Samuel van der Zee and Nathan Samuels, Sara Pallache and Abraham Nathans before Notary Nicolaes Hemmich in Amsterdam, 18 June 1681. This trick was meant to impress the family.

111 Ibid., testimony of Jeronimo Poens, Mechelen, 19 July 1681.

112 For the request of appeal to the Dutch Hoge Raad see ibid., 4 September 1681; see also ibid., 18 November 1681; for the final sentence NL-HaNA, Hoge Raad van Holland en Zeeland, entry no. 3.03.02, ibid. inv. no. 903, 22 July 1684, scan no. 221.

113 Rebecca Pallache refers to the first decision to disinherit her daughter in her last will: "ende vooral $t$ approberen van waarde te houden als sulke testamente als zij compt voor de ed Heere Benjamin Fagel y Francois Ketelaer raden van den hove van Hollant [...] heeft gepasseert gelast in dato 29 juni 1682." In fact, Rebecca might have followed the policy of her grandfather toward her father Isaac, who was deprived of his mother's part of the inheritance because of his conversion to Christianity. A lengthy lawsuit ensued between father and son like the one between Rebecca and her daughter, see García-Arenal and Wiegers, Samuel Pallache, 223-24. Hugo de Groot, Remonstrantie, 29-30, n. 57. For parents disinheriting their children in case they disagreed with the choice of a marriage partner, 
decision in her last will just before she died in 1685 , and justified her decision by citing her daughter's repeated complaints and reproaches despite the fact that she had helped her by sending money to relieve her financial situation. ${ }^{114}$ In order to ensure that what happened with Eva will not be repeated, she further stipulated that should any of her other children marry without permission of the guardians she appointed to take over their care after her death, they would lose their inheritance as well. ${ }^{115}$ Her son Mordechay unsuccessfully tested this provision a few years later. ${ }^{116}$

see Haks, Huwelijk en Gezin, 116. Ariadne Schmidt, “'Touching Inheritance'. Mannen, vrouwen en de overdracht van bezit in Holland in de 17e eeuw," Holland 33, no. 3 (2001): 177.

114 Last will of Rebecca Pallache: SAA 5075, inv. no. 3696, Not. F. Tixerandet, 20 August 1685.

115 This way Rebecca limited and directed the rights of inheritance of her children: she was ready to give them legacies under strict conditions and supervision only. She allocated supreme power to the guardians she appointed, till her sons would reach the age of thirty. Even after that age, these guardians would keep some influence if the children remained unmarried. If her sons would get married before the age of 30 then they could only marry with complete consent of the guardians (SAA 5075, inv. no. 3696, Not. F. Tixerandet, 20 August 1685). No word about restriction for her daughter Ester in this respect; for her a large sum and gifts in natural including many pieces of silverwork, jewelry and linen were reserved. Apparently her partner was already chosen and all settlements arranged: we have yet to find them. Eventually, Eva's sister Ester, married in 1694, then 22 years old: see registration of intended marriage SAA DTB 698, p. 284, 23 April 1694. The groom she married was Samuel de Nathan Pallache (Eva's intended spouse?; the one who chased her in London), a merchant 36 years old, living in Oude Zijds Houttuinen in Amsterdam, while Ester was living at Nieuwe Herengracht, in Amsterdam at the time of her marriage. Her guardian Isaac Abrabanel was present at the registration and contrary to what happened at the registration of the marriage of Mordechay, one of Rebecca's sons, six years earlier, in 1688, gave his consent in agreement with Rebecca's last will. Ester died young, in 1699, at the age of around 27. Therefore it is written on her grave "incurtada": http://www.dutchjewry .org/P.I.G./image/01918001.jpg; for the registration of her burial SAA 334, inv. no. 916, p. 119, 12 Adar II 5459. Twelve days later, on 24 Adar II, her husband Samuel Pallache reserved two graves next to her, for himself and their child? (ibid., 24 Adar II). In accordance with Rebecca's will, the guardians refused to approve to the registration of marriage of son Mordechay who converted to Christianity and married a non-Jewish woman in 1688 (SAA Dтв 517, p. 167, 10 July 1688: Franciesco Pedro de Cohen alias Mordochaij Cohen, 22 years old, living at Singel and Maria Catharina Vakeles alias Catharina Vakeles, living at the same address, father abroad); the commissioners looked into the matter and the registration was therefore delayed. Meanwhile, to get the matter moving and apparently under pressure of the guardians, three days after his first effort to get his marriage registered, Mordechay renounced his mother's inheritance as he did not want to comply with her conditions (SAA entry no. 5075, inv. no. 3704, Not. F. Tixerandet, pp. 106-109, 13 July 1688). Only on 22 July the city commissioners gave permission and on 28 July the matter was finally settled through an agreement with Mordechay's guardians. For inheritance law in Holland see Schmidt, “'Touching inheritance," $175^{-89}$.

116 For Mordechay marrying a non-Jewish woman without consent of his guardians, see above n. 115 . 
Michiel and Eva lived in poverty. ${ }^{117}$ The couple eventually settled in England, but the exact location and date remain unknown. Michiel died around fifteen years after the verdict of the Supreme Court, apparently as a soldier, sometime in the 169os, certainly before 1699. In that year, one Elisabeth Cohen widow of Michiel Verboon is mentioned in a deed before an Amsterdam notary, Mr. Pelgrom. Eva was remarried to one Francois van Spijck, and apparently was trying to extract some financial benefits from her father's assets. ${ }^{118} \mathrm{Her}$ whereabouts are still unclear at this point: did she live in Holland or England or elsewhere? Most likely, she lived in England: a document from 1720 from Chester, England deals with the inheritance of Elisabeth Verboon to be handed over to her daughter Catherine Verboon. ${ }^{119}$ We can assume then that Elisabeth Verboon, nee Eva Cohen died around that time.

\section{8}

\section{Conclusion}

The dispute surrounding Eva Cohen offers us an extraordinary opportunity to look behind the coulisses into Sephardic family life over the course of the seventeenth century. In this specific case, but which is applicable to quite a few other Sephardic families, connections to the organized Jewish community were not strongly fixed, social status was high on the agenda, and signs of integration into Dutch society were easily visible.

The study also exposes the motivations behind conversion at that time, which seem to have been a blend of religious, economic, social, and emotional parameters. Among the Portuguese Jews, the reaction to conversion to Christianity was vehement and harsh, and was even more so when it involved a well-to-do family that saw its wealth threatened, its Jewish heritage negated, and its Sephardic pride tarnished.

At the same time, the case offers an opportunity to gather new data on the neglected field of research into the status of women among the Dutch Sephardim in early modern times. It particularly highlights the position of the

117 This fact was already attested to in the last will of Rebecca Pallache: SAA 5075, inv. no. 3696, Not. F. Tixerandet, 20 August 1685: "alsoo Eva Cohen haar dochter tot uiterste armoede vervallen was."

118 Eva's second husband went to the notary on her behalf to ask for authentic extracts out of the books of the West Indian Company, Chamber of Amsterdam, relating to a deal involving salt from Portugal, in which Eva's father, Abraham Cohen apparently had an interest: SAA 5075, inv. no. 4774, Not. S. Pelgrom, pp. 729-730, 8 December 1699. With many thanks to Ton Tielen who provided me with these documents.

119 Elizabeth Verboon of Chester, February 1720: Chester Archives and Local Studies, WS 1720. Elizabeth did not leave a will so that her daughter Catherine needed legal assent to dispose of Eva's money and belongings. 
community's young girls and widows, their background, education, and skills, their interactions within the family and with the world at large, and their ability to strike a path of their own despite obstacles on the way. The extraordinary documents that survive from this case, like the letters and interviews, offer rare insights into female emotions and expressions, all of which further our knowledge about the complexities of Sephardic identity in early modern times.

\section{Bibliography}

Apeldoorn, Lambertus J. Van. Geschiedenis van het Nederlandsche huwelijksrecht vóór de invoering van de Fransche wetgeving. Amsterdam: Holland, 1925.

Bloom, Herbert I. "The Dutch Archives with Special Reference to American Jewish History." Publications of the American Jewish Historical Society 32 (1931): 7-21.

Bodian, Miriam. “The 'Portuguese' Dowry Societies in Venice and Amsterdam: A Case Study in Communal Differentiation within the Marrano Diaspora." Italia 6, nos. 1-2 (1987): 30-61.

Bosman, Machiel. Elisabeth de Flines. Een onmogelijke liefde in de achttiende eeuw. Amsterdam: Athenaeum-Polak \& Van Gennep, 2008.

Boxer, Charles R. The Dutch in Brazil, 1624-1654. Oxford: The Clarendon Press, 1957.

Burnet, Gilbert. De ware bekeringe en violente vervolgingen van Eva Cohen, nu genaemt Elisabeth. Zijnde een persoon van qualiteyt vande Joodsche gesintheyt geweest, ende gewoont hebbend tot Delft; dewelke gedoopt is den 10. October, 1680 in St. Martins Kerck, des Coninghs Parochie van Whitehall, door den seer Eerwaardieghen Heer William Floid, bisschop van St. Asaph (no place; no date).

Burnet, Gilbert. The Conversion \& Persecutions of Eve Cohan, Now called Elizabeth Verboon, a Person of Quality of the Jewish Religion, Who was Baptized the roth of October, 1680, at St. Martins in the Fields by the Right Reverend Father in God, William, Lord Bishop of St. Asaph (London, 1680).

Carlebach, Elisheva. Divided Souls: The Convert Critique and the Culture of Ashkenaz 1750-180o. New York: Leo Baeck Institute, 2003.

Eekhout, Luc L.M. “De Delftse Kamer van de VOC.” In De stad Delft. Cultuur en Maatschappij van 1572 tot 1667. Vol 2. Edited by Ineke V.T. Spaander, 2: 90-94. Delft: Stedelijk Museum "Het Prinsenhof," 1981.

Emmanuel, Isaac S. "Seventeenth-Century Brazilian Jewry: A Critical Review." American Jewish Archives 14, no. 1 (April 1962): 32-68.

Endelman, Todd M. Leaving the Jewish Fold. Conversion and Radical Assimilation in Modern Jewish History. Princeton, NJ: Princeton University Press, 2015.

Endelman, Todd M. Radical Assimilation in English Jewish History, 1656-1945. Bloomington: Indiana University Press, 1990. 
Franco Mendes, David. Memorias do estabelecimento e progresso dos judeos portuguezes e espanhoes nesta famosa citade de Amsterdam. Edited by Lajb Fuks and Reina G. Fuks-Mansfeld; commentary Benjamin N. Teensma. Assen: van Gorcum, 1975 .

García-Arenal, Mercedes, and Gerard Wiegers. Samuel Pallache. Koopman, kaper en diplomaat tussen Marrakesh en Amsterdam. Amsterdam: Amsterdam University Press, 2014 .

Gelfand, Noah L. "To Live and to Trade. The Status of Sephardi Mercantile Communities in the Atlantic World during the Seventeenth and Eighteenth Centuries." In The Jews in the Caribbean. Edited by Jane S. Gerber, 45-64. Oxford: The Littman Library of Jewish Civilization, 2014.

Gonsalves de Mello, José A. Gente de Nação: Cristãos-Novos e Judeus em Pernambuco, 1542-1654. Recife: Massangana, 1989.

Gottlieb, Beatrice. The Family in the Western World from the Black Death to the Industrial Age. New York: Oxford University Press, 1993.

De Groot, Hugo. Remonstrantie nopende de ordre dije in de landen van Hollandt ende Westvrieslandt dijent gestelt op de Joden. Edited with an introduction by Jaap Meijer. Amsterdam: Joachimsthal's Boekhandel, Uitgevers-en Drukkerbedrijf N.V., 1949 [5709].

Haks, Donald. Huwelijk en Gezin in de 17de en 18de Eeuw. Assen: van Gorcum, 1982.

Hulshof, A. "Een Duitsch econoom in en over ons land omstreeks 1670." Onze Eeuw 10 (1910): 5-96.

Hyamson, Albert M. The Sephardim of England, A History of the Spanish and Portuguese Jewish Community 1492-1951. London: Methuen, 1951.

Israel, Jonathan I. Diasporas within a Diaspora. Jews, Crypto Jews and the World Maritime Empires (1540-1740). Leiden: Brill, 2002.

Kagan, Richard, and Philip D. Morgan, eds. Atlantic Diasporas. Jews, Conversos and Crypto-Jews in the Age of Mercantilism 1500-180o. Baltimore: The Johns Hopkins University Press, 2009.

Kaplan, Benjamin J. Divided by Faith. Religious Conflict and the Practice of Toleration in Early Modern Europe. Cambridge, MA: The Belknap Press of Harvard University Press, 2007.

Kaplan, Yosef. "Clandestine Marriage in Amsterdam, Broken Hearts in Hamburg and a Kidnapping in London." (Hebrew). In Tov Elem: Memory, Community and Gender in Medieval and Early Modern Societies, Essays in Honor of Robert Bonfil. Edited by Elisheva Baumgarten, Amnon Raz-Krakotzkin, Roni Weinstein, 171-90. Jerusalem: Mosad Bialik, 2011.

Kaplan, Yosef. "De joden in de Republiek tot omstreeks 1750: religieus, cultureel en sociaal leven." In Geschiedenis der Joden in Nederland. Edited by Hans Blom, David Wertheim, Hetty Berg, Bart Wallet, 131-96. Amsterdam: Balans, 2017. 
Kaplan, Yosef. "Moral Panic in the Eighteenth-Century Sephardi Community of Amsterdam: The Threat of Eros." In Dutch Jewry: Its History and Secular Culture. Edited by Jonathan I. Israel and Reinier Salverda, 103-23. Leiden: Brill, 2002.

Kaplan, Yosef. "The Social Functions of the Herem in the Portuguese Jewish Community of Amsterdam in the Seventeenth Century." In Dutch Jewish History. 2 vols. Edited by Jozeph Michman and Tirtsah Levie [Bernfeld], 1: 111-55. Jerusalem: Institute for Research on Dutch Jewry, 1984.

Katz, Jacob. Tradition and Crisis. Jewish Society at the End of the Middle Ages. Translated and with an afterword and bibliography by Bernard D. Cooperman. Syracuse, NY: Syracuse University Press, 2000.

Levie Bernfeld, Tirtsah. Dowries and Dotar. An Unbroken Chain of 400 Years. Amsterdam: Menasseh ben Israel Institute, 2015.

Levie Bernfeld, Tirtsah. "Masters, Maids and Mistresses: Aspects of Domestic Life among the Portuguese Jews in the Seventeenth-Century Dutch Republic." In Sephardische Perspektiven: Viertes Jahrbuch des Selma Stern Zentrums Jüdische Studien Berlin-Brandenburg. Edited by Sina Rauschenbach. Berlin/Leipzig: Hentrich \& Hentrich, forthcoming: 2019 .

Levie Bernfeld, Tirtsah. "Matters Matter: Material Culture of Dutch Sephardim." Studia Rosenthaliana 44 (2012): 191-216.

Levie Bernfeld, Tirtsah. Poverty and Welfare among the Portuguese Jews in Early Modern Amsterdam. Oxford: The Littman Library of Jewish Civilization, 2012.

Levie Bernfeld, Tirtsah. "Religious Life among Portuguese Women in Amsterdam's Golden Age." In The Religious Cultures of Dutch Jewry. Edited by Yosef Kaplan and Dan Michman, 57-99. Leiden: Brill, 2017.

Levie Bernfeld, Tirtsah. "Sephardi Women in Holland's Golden Age." In Sephardi Family Life in the Early Modern Period. Edited by Julia R. Lieberman, 177-222. Waltham, MA: Brandeis University Press, 2010.

Meijer, Jaap. Encyclopaedia Sefardica Neerlandica 2 vols. Amsterdam: Portugees-Israelietische Gemeente Amsterdam, 5709-5710 [1948-1950].

Meilink-Hoedemaker, Laura J. "Uurwerken, Luidklokken en Klokkenspellen te Delft." In De stad Delft. Cultuur en Maatschappij van 1572 tot 1667. Vol. 2. Edited by Ineke V.T. Spaander, 238-241. Delft: Stedelijk Museum "Het Prinsenhof," 1981.

Montias, John Michael. Artists and Artisans in Delft. A Socio-Economic Study of the Seventeenth Century. Princeton, NJ: Princeton University Press, 1982.

Oppenheim, Samuel. "The Early History of the Jews in New York, 1654-1664," Publications of the American Jewish Historical Society 18 (1909): 3-91.

Opstall, Margaretha E. van."De kamer van de Maze tot Delft." In De stad Delft. Cultuur en Maatschappij van 1572 tot 1667. Vol 2. Edited by Ineke V.T. Spaander, 2: 94-100. Delft: Stedelijk Museum "Het Prinsenhof," 1981. 
Pieterse, Wilhelmina Chr. Daniel Levi de Barrios als geschiedschrijver van de PortugeesIsraelietische gemeente te Amsterdam in zijn "Triumpho del govierno popular." Amsterdam: Publikaties van de Gemeentelijke Archiefdienst van Amsterdam, 1968.

Roodenburg, Herman. Onder Censuur. De kerkelijke tucht in de gereformeerde gemeente van Amsterdam, 1578-170o. Hilversum: Verloren, 1990.

Roosenboom, Henk Th. M. Ontvoerd of gevlucht? Religieuze spanningen in Brabant en de zaak Sophia Alberts 1700-1710. Hilversum: Verloren, 2016.

Schledorn, Loet. "De kamer van Delft van de VOC: een rijke bron." In Burgers verzamelen, 1600-175o Schatten in Delft 1602-2002; 400 jaar Verenigde Oost-Indische Compagnie. Edited by Ellinoor Bergvelt, Michiel Jonker, Agnes Wiechmann,143-155. Zwolle: Waanders, 2002.

Schmidt, Ariadne. Overleven na de dood. Weduwen in Leiden in de Gouden Eeuw. Amsterdam: Prometheus/Bakker, 2001.

Schmidt, Ariadne. “Touching Inheritance'. Mannen, vrouwen en de overdracht van bezit in Holland in de 17e eeuw." Holland 33, no. 3 (2001): 175-189.

Schmidt, Ariadne. "Vrouwen en het recht. De juridische status van vrouwen in Holland in de vroegmoderne tijd." Jaarboek van het Centraal Bureau voor Genealogie $5^{8}$ (2004): 27-44.

Swetschinski, Daniel M. Reluctant Cosmopolitans, The Portuguese Jews of SeventeenthCentury Amsterdam. London: The Littman Library of Jewish Civilization, 2000.

Vente, Maarten A. "Aspecten van de Delftse Muziekgeschiedenis." In De stad Delft. Cultuur en Maatschappij van 1572 tot 1667. Vol. 2. Edited by Ineke V.T. Spaander, 232-35. Delft: Stedelijk Museum "Het Prinsenhof," 1981.

Verhoeven, Gerrit. De derde stad van Holland. De geschiedenis van Delft tot 1795. Zwolle: WBOOKS, 2015.

Wiznitzer, Arnold. Jews in Colonial Brazil. New York: Columbia University Press, 1960.

Wolff, Egon and Frieda. Dicionário Biográfico, Judaizantes e Judeus no Brasil 1500-1808. Rio de Janeiro: E.\&F. Wolff, 1986.

Zwarts, Jac. "Assimilatiepogingen van overheidswege." In Hoofdstukken uit de Geschiedenis der Joden in Nederland. Edited by Jac. Zwarts,130-55. Zutphen: W.J. Thieme, 1929.

Zwarts, Jac. “De Joodse gemeenten buiten Amsterdam." In Geschiedenis der Joden in Nederland. Edited by Henk Brugmans and Abraham Frank, 382-453. Amsterdam: Van Holkema \& Warendorf, 1940. 